\title{
Communication
}

\section{Comprehensive Analysis of Correlations in the Expression of miRNA Genes and Immune Checkpoint Genes in Bladder Cancer Cells}

\author{
Przemysław A. Stempor ${ }^{1}{ }^{1}$, Dror Avni ${ }^{2}$, Raya Leibowitz ${ }^{3,4}$, Yechezkel Sidi ${ }^{4}$, Maria Stępień ${ }^{5}$, \\ Tomasz Dzieciątkowski ${ }^{6}$ and Paula Dobosz ${ }^{7, *}$ \\ 1 SmartImmune Ltd, Accelerate Cambridge, University of Cambridge Judge Business School, \\ Cambridge CB4 1EE, UK; pstempor@gmail.com \\ 2 Laboratory of Molecular Cell Biology, Center for Cancer Research and Department of Medicine C, \\ Sheba Medical Center, Tel Hashome 52621, Israel; droravni@msn.com \\ 3 Oncology Institute, Shamir Medical Center, Be'er Yaakov, Tel Hashome 52621, Israel; rayal@shamir.gov.il \\ 4 Faculty of Medicine, Sackler School of Medicine, Tel Aviv University, Tel Aviv-Yafo 6997801, Israel; \\ yehezkel.sidi@sheba.health.gov.il \\ 5 Faculty of Medicine, Medical University of Lublin, 20-059 Lublin, Poland; mmaria.stepien@gmail.com \\ 6 Department of Microbiology, Medical University of Warsaw, 02-005 Warsaw, Poland; dzieciatkowski@wp.pl \\ 7 Department of Hematology, Transplantationand Internal Medicine, Medical University of Warsaw, \\ 02-097 Warsaw, Poland \\ * Correspondence: paula.dobosz@wum.edu.pl
}

check for

updates

Citation: Stempor, P.A.; Avni, D.; Leibowitz, R.; Sidi, Y.; Stępień, M.; Dzieciątkowski, T.; Dobosz, P.

Comprehensive Analysis of

Correlations in the Expression of miRNA Genes and Immune

Checkpoint Genes in Bladder Cancer Cells. Int. J. Mol. Sci. 2021, 22, 2553.

https://doi.org/10.3390/ijms22052553

Academic Editor: Bartosz Jan Płachno

Received: 26 January 2021

Accepted: 23 February 2021

Published: 4 March 2021

Publisher's Note: MDPI stays neutral with regard to jurisdictional claims in published maps and institutional affiliations.

Copyright: (C) 2021 by the authors Licensee MDPI, Basel, Switzerland. This article is an open access article distributed under the terms and conditions of the Creative Commons Attribution (CC BY) license (https:/ / creativecommons.org/licenses/by/ $4.0 /)$.

\begin{abstract}
Personalised medicine is the future and hope for many patients, including those with cancers. Early detection, as well as rapid, well-selected treatment, are key factors leading to a good prognosis. MicroRNA mediated gene regulation is a promising area of development for new diagnostic and therapeutic methods, crucial for better prospects for patients. Bladder cancer is a frequent neoplasm, with high lethality and lacking modern, advanced therapeutic modalities, such as immunotherapy. MicroRNAs are involved in bladder cancer pathogenesis, proliferation, control and response to treatment, which we summarise in this perspective in response to lack of recent review publications in this field. We further performed a correlation-based analysis of microRNA and gene expression data in bladder cancer (BLCA) TCGA dataset. We identified 27 microRNAs hits with opposite expression profiles to genes involved in immune response in bladder cancer, and 24 microRNAs hits with similar expression profiles. We discuss previous studies linking the functions of these microRNAs to bladder cancer and assess if they are good candidates for personalised medicine therapeutics and diagnostics. The discussed functions include regulation of gene expression, interplay with transcription factors, response to treatment, apoptosis, cell proliferation and angiogenesis, initiation and development of cancer, genome instability and tumour-associated inflammatory reaction.
\end{abstract}

Keywords: miRNA; microRNA; bladder cancer; noncoding RNAs; immune checkpoints; immunological synapse

\section{Introduction}

Traditionally, cancer patients have been prescribed their medications based on the tissue of origin, but also symptoms and signs of their disease, according to the rule "one size fits all" [1]. Personalised medicine is a leading medical model proposing customisation of healthcare [1,2]. According to this strategy, treatment and all medical procedures should be tailored to the particular patient, especially to their genetic makeup, not only the disease. Thus, stratified medicine is a concept based on identifying subgroups of patients having distinct characteristics, mechanisms of disease or responses to treatment [3].

Not only the treatment is tailored in this concept, it also requires very precise diagnostic tests, able to identify a subgroup of patients which will benefit from the treatment 
or those patients whose health might be at risk when given certain drugs. Particularly prominent diagnostic procedures include genomics-based molecular methods, with the aid of imaging and analytical/bioinformatical tools. Development of molecular personalised medicine requires interdisciplinary teams composed of medical and biological specialities. It requires a good understanding of human organism complexity, environmental exposures, genomic interactions and the disease process itself [1].

Unfortunately, precision medicine is being implemented very slowly in cancer management. The need for good biomarkers is more urgent than ever. For example, platinum-based chemotherapy and/or cystectomy remain the major clinical interventions undertaken for bladder cancer patients. However, the only factors considered for the selection of therapy are the disease progression and responsiveness to chemotherapy [4,5]. Given the incredible progress in immunotherapy, the need for clinically useful biomarkers and molecular methods for patient stratification is obvious, as only approximately $50 \%$ of the patients respond to chemotherapy. Another group responds well to checkpoint inhibitors (in most cases $15-30 \%$; depending on the drug and trial, it can be up to $46 \%$ ) to give some examples [4].

MicroRNAs (miRNAs, miRs) are abundant small non-coding RNAs composed of 22-24 nucleotides [6,7]. They play an important role in post-transcriptional gene suppression [8] and have been reported to be involved in cellular processes, such as differentiation, morphogenesis and tumorigenesis [8,9]. miRNAs usually target the 3 'unranslated region (UTR) of the mRNA and less frequently the $5^{\prime}$ UTR or the coding sequence of their target mRNA [9]. Thus, miRNAs regulate gene expression, and each miRNA molecule targets tens to hundreds of mRNAs [6]. Furthermore, some mRNA targets might be combinatorically affected by several different miRNA molecules, increasing the complexity and precision of post-transcriptional regulation, and fine-tuning the expression level of genes [6]. Aberrant miRNA expression is found in a variety of cancers, including bladder cancer, suggesting that they may have roles as oncogenes or tumour-suppressor genes [8]. Half of all the miRNA genes are located in genomic regions known to be associated with cancer or in fragile sites often altered in human cancers [9]. These observations clearly show the importance of miRNAs function in cancer.

Selected groups of specific miRNAs are commonly altered in particular cancers, and recent data have shown that miRNA expression profiles of tumours are able to discriminate between different types of cancer [10]. Thus, miRNA profiles might be more useful for cancer diagnosis and prognosis [11], whereas profiles based only on mRNA have been proven to be generally unreliable, to date [10]. Several miRNA:mRNA interactions have been proven to be important for cancer pathogenesis so far, with let-7 miRNA family being the most well-studied [12]. The family of miR let-7 regulates RAS oncogenes, among others, and the expression of let-7 is reduced in several tumours, including lung cancer [12].

At the moment, there are no reliable molecular biomarkers for bladder cancer prognosis, treatment, response or progression, despite advances achieved through novel checkpoint therapies $[13,14]$. Significant effort has been invested in unravelling predictive biomarkers for the response to immune checkpoint inhibition in many cancers, including bladder cancer, melanoma or lung cancer $[13,15]$. PD-1/PD-L1 expression in tumour cells and in the tumour microenvironment, genetic alterations, mutational load in tumour cells, epigenetic changes, miRNAs expression, pre-existing immunity and its enhancement during treatment by the tumour-infiltrating immune cells were associated with better outcomes and were shown to be predictors for immune checkpoint inhibition. However, further studies are required to assess their predictive power and facilitate the implementation into the clinic $[13,15]$. In this paper, we present results from a comprehensive bioinformatical analysis of the correlation between the expression of 21 genes known to be involved in the immunological synapse and miRNAs in bladder cancer. We also added three transcription factors discovered in our previous work [16] to be positively correlated with the expression of selected checkpoint mRNAs from the network we previously reported. 


\section{Results}

\subsection{Correlations Analyses in Bladder Cancer Samples-Genes mRNA to miRNA}

In this study, we investigated co-expression profiles of miRNAs and co-inhibitory and co-stimulatory checkpoint genes potentially involved in the immunological synapse. To facilitate this task, we visualised the correlations as both static and interactive heatmaps for the bladder cancer dataset available in The Cancer Genome Atlas (TCGA). This resource is now available publicly as an interactive website (see Supplementary Materials Section, Figures S1 and S2).

In order to create a good starting point for further investigations aiming to assess regulatory dependencies and genetic interactions between genes and microRNAs, we calculated correlations between all miRNAs and a selected set of 21 genes, known from the literature to be potentially expressed on the cancer side of the immunological synapse: CD112, CD137L, CD200, CD276, CD277, CD40, CD48, CD70, CD80, CD86, GITRL, HHLA2, HVEM, ICOSLG, LGALS9, OX40L, PD-L1, PD-L2, PVR, VISTA and VTCN1. To present a more complete picture of regulation, we also included three transcription factors (TFs), which we identified in our previous research to be correlated with the co-expressed checkpoint genes in this set: BACH2, MAFK and NFE2L2 [16].

We chose to further study miRNAs that are negatively correlated with gene expression under our assumptions that these may directly negatively regulate one of the genes of interest. Conversely, positive correlation might indicate indirect regulation; for example, miRNAs that negatively regulate suppressors of the genes of interest, but may also indicate more complex crosstalk. Using these criteria, we obtained $27 \mathrm{miRNAs}$ generally anti-correlated with gene expression: hsa - mir $-30 \mathrm{~d}$, mir-4778, mir-1306, mir-4756, mir-1287, mir-96, mir-3200, mir-187, mir-93, mir-423, mir-219a-1, mir-98, mir-182, mir-1307, mir-744, mir-301b, mir-940, mir-151a, mir-3193, mir-183, mir-191, mir-141, mir-7706, mir-200c, mir-429, mir-200b and mir-200a (Figure 1).

The correlation profiles of all 27 miRNAs are very similar, suggesting that they all contribute to the co-suppression of immune synapse genes. However, their correlation with genes is not uniform: CD48 CD70, CD80, CD86, OX40L and PD-L2 are most strongly anticorrelated to miRNA expression, indicating that this cluster of genes is under the strongest control. In the previous report [16], we found most of these genes to be strongly correlated with each other and possibly working together in synergy. At the same time, the results suggest the existence of a second set of genes that are not anticorrelated or weakly correlated with the set of putative downregulating miRNAs: CD112, VEM, ICOSLG, LGALS9 and VTCN1. Interestingly, we found these genes correlated with other genes in the immune response set-this intuitively suggests that not all, but only a specific subset of immune response genes is under specific miRNA control.

The TCGA database contains the expression levels of pre-miRNAs and not of the mature miRNAs. Some of the top correlated and anticorrelated miRNAs, for example, mir199a-1 and mir-199a-2, have different pre-miRNA sequence, but produce identical mature miRNA, and are extremely likely to target the same genes. Furthermore, among our top hits, there are miRNAs, which have a different mature sequence, but share the same seed region such as mir-146a and mir-146b, and are also likely to target the same genes. However, their transcriptional and post-transcriptional regulation might be different, and they can potentially perform different functions depending on transcription of other miRNAs and coding genes. We observed identical correlation profiles for some miRNAs sharing the mature sequence (mir-125b-1 and mir-125b-2). However, the expression profiles were similar, but not identical for miRNAs, sharing only the seed region: mir-146a and mir-146b; mir-199a and mir-199b. Additionally, mir-199a-1 and mir-199a-2, despite sharing an identical sequence, had similar, but not identical correlation profiles. 


\section{TCGA - BLCA: mRNA - miRNA correlations}

$p$-value $<0.01$ and mean $R<-0.2$

Correlation $-1.0 \quad-0.5 \quad 0.0 \quad 0.5 \quad 1.0$

\begin{tabular}{|c|c|c|c|c|c|c|c|c|c|c|c|c|c|c|c|c|c|c|c|c|c|c|c|c|}
\hline & 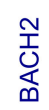 & $\underset{⿱ 亠 乂}{\mathbb{4}}$ & 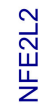 & $\frac{N}{\frac{N}{5}}$ & 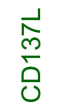 & $\begin{array}{l}\text { О } \\
\text { Oิ } \\
\text { U }\end{array}$ & $\begin{array}{l}\stackrel{0}{N} \\
\text { กิ } \\
\text { u. }\end{array}$ & $\begin{array}{l}\widehat{N} \\
\text { ปิ }\end{array}$ & $\begin{array}{l}\text { \& } \\
\text { Oे }\end{array}$ & $\begin{array}{l}\text { @ } \\
\text { ல }\end{array}$ & $\begin{array}{l}\text { ㅇ } \\
\text { O }\end{array}$ & $\begin{array}{l}\stackrel{\circ}{\infty} \\
\text { Oे }\end{array}$ & $\begin{array}{l}\varrho \\
\stackrel{0}{0} \\
\text { U }\end{array}$ & $\frac{\overrightarrow{\underline{Y}}}{\frac{\vec{E}}{\mathbb{V}}}$ & $\begin{array}{l}\text { 等 } \\
\text { 至 }\end{array}$ & $\underset{⿱ 亠 䒑}{\stackrel{\sum}{\Psi}}$ & $\begin{array}{l}\text { U } \\
\text { W0 } \\
\underline{0}\end{array}$ & 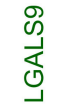 & $\begin{array}{l}\text { 뭉 } \\
\text { 丈̀ }\end{array}$ & $\begin{array}{l}َ \\
\\
0 \\
0\end{array}$ & $\begin{array}{l}\text { Y } \\
1 \\
0 \\
0\end{array}$ & $\stackrel{\Upsilon}{\stackrel{\alpha}{\alpha}}$ & $\begin{array}{l}\frac{\sigma}{6} \\
\stackrel{\infty}{>}\end{array}$ & $\begin{array}{l}\bar{z} \\
\text { U. } \\
5\end{array}$ \\
\hline hsa-mir-30d & & 0.1 & 0 & 0.2 & -0.4 & -0.2 & -0.3 & -0.2 & 0 & -0.3 & -0.4 & -0.4 & -0.5 & -0.2 & -0.1 & 0.2 & 0 & 0 & -0.4 & -0.3 & -0.5 & -0.4 & -0.2 & 0.2 \\
\hline hsa-mir-4778 & & 0 & 0 & 0.1 & -0.3 & -0.2 & -0.2 & -0.1 & -0.1 & -0.4 & -0.4 & -0.4 & -0.4 & -0.3 & -0.1 & 0.1 & 0 & 0 & -0.4 & -0.4 & -0.5 & -0.3 & -0.3 & .1 \\
\hline hsa-mir-1306 & 0. 3 & 0 & -0.2 & 0 & -0.2 & -0.3 & 0 & -0.2 & -0.3 & -0.4 & -0.3 & -0.3 & -0.3 & -0.2 & -0.1 & -0.2 & -0.1 & -0.2 & -0.4 & -0.2 & -0.3 & -0.1 & -0.4 & -0.1 \\
\hline hsa-mir-4756 & & 0.1 & 0 & 0 & -0.4 & -0.2 & -0.2 & -0.2 & -0.1 & -0.3 & -0.5 & -0.4 & -0.4 & -0.2 & -0.1 & 0.2 & 0 & 0 & -0.4 & -0.4 & -0.5 & -0.4 & -0.1 & 0 \\
\hline hsa-mir-1287 & 4 & 0.1 & 0 & 0.1 & -0.4 & -0.2 & -0.2 & -0.1 & -0.1 & -0.4 & -0.4 & -0.4 & -0.4 & -0.2 & -0.1 & 0.2 & -0.1 & 0 & -0.4 & -0.4 & -0.5 & -0.4 & -0.1 & 0 \\
\hline hsa-mir-96 & 4 & 0 & 0 & 0.2 & -0.2 & -0.3 & -0.1 & -0.2 & -0.3 & -0.4 & -0.3 & -0.3 & -0.4 & -0.3 & -0.2 & 0 & 0.1 & 0 & -0.4 & -0.3 & -0.5 & -0.2 & -0.4 & 0.2 \\
\hline hsa-mir-3200 & 0.4 & -0.1 & -0.1 & 0.1 & -0.2 & -0.3 & -0.1 & -0.2 & -0.2 & -0.4 & -0.4 & -0.4 & -0.4 & -0.2 & 0 & -0.1 & -0.1 & -0.1 & -0.3 & -0.3 & -0.4 & -0.1 & -0.4 & 0 \\
\hline hsa-mir-187 & 4 & 0.1 & 0.1 & 0.1 & -0.3 & -0.2 & -0.1 & -0.2 & -0.2 & -0.4 & -0.4 & -0.4 & -0.4 & -0.2 & -0.1 & 0 & 0 & -0.1 & -0.4 & -0.4 & -0.5 & -0.3 & -0.2 & 0.1 \\
\hline hsa-mir-93 & .4 & 0 & -0.1 & 0.1 & -0.2 & -0.3 & -0.1 & -0.2 & -0.2 & -0.4 & -0.3 & -0.3 & -0.4 & -0.2 & -0.1 & 0 & 0 & -0.1 & -0.4 & -0.3 & -0.5 & -0.2 & -0.3 & 0 \\
\hline hsa-mir-423 & & 0 & 0 & 0.1 & -0.2 & -0.4 & -0.2 & -0.2 & -0.2 & -0.4 & -0.3 & -0.3 & -0.4 & -0.2 & -0.1 & 0 & -0.1 & 0 & -0.5 & -0.2 & -0.4 & -0.2 & -0.4 & 0 \\
\hline a-mir- & 0.4 & 0 & 0.1 & 0.1 & -0.2 & -0.4 & -0.2 & -0.2 & -0.1 & -0.4 & -0.3 & -0.4 & -0.4 & -0.2 & -0.1 & -0.1 & -0.1 & -0.1 & -0.5 & -0.3 & -0.5 & -0.2 & -0.3 & 0 \\
\hline hsa-mir-98 & 0.4 & 0 & -0.1 & 0 & -0.3 & -0.2 & -0.2 & -0.3 & -0.3 & -0.4 & -0.4 & -0.3 & -0.4 & -0.2 & -0.2 & -0.1 & 0 & -0.2 & -0.4 & -0.3 & -0.4 & -0.2 & -0.3 & 0.1 \\
\hline hsa-mir-182 & 0.4 & 0 & 0 & 0.1 & -0.3 & -0.3 & -0.2 & -0.3 & -0.3 & -0.4 & -0.4 & -0.4 & -0.5 & -0.2 & -0.2 & -0.1 & 0 & 0 & -0.4 & -0.3 & -0.5 & -0.3 & -0.4 & .2 \\
\hline hsa-mir-1307 & & 0 & -0.1 & 0 & -0.2 & -0.4 & -0.2 & -0.3 & -0.2 & -0.4 & -0.3 & -0.3 & -0.4 & -0.2 & -0.1 & -0.1 & -0.1 & -0.1 & -0.5 & -0.2 & -0.4 & -0.2 & -0.2 & -0.1 \\
\hline hsa-mir-744 & -0.3 & 0 & -0.1 & 0 & -0.1 & -0.4 & -0.1 & -0.3 & -0.3 & -0.4 & -0.3 & -0.3 & -0.4 & -0.2 & -0.1 & -0.2 & -0.1 & -0.3 & -0.4 & -0.2 & -0.4 & -0.1 & -0.4 & -0.1 \\
\hline hsa-mir-301b & 0.4 & 0 & -0.2 & 0.1 & -0.2 & -0.3 & -0.1 & -0.3 & -0.3 & -0.5 & -0.3 & -0.4 & -0.4 & -0.3 & -0.2 & -0.1 & -0.1 & -0.2 & -0.4 & -0.3 & -0.4 & 0 & -0.4 & 0 \\
\hline hsa-mir-940 & 3 & 0 & -0.1 & 0 & -0.2 & -0.3 & -0.2 & -0.3 & -0.3 & -0.4 & -0.3 & -0.4 & -0.4 & -0.2 & -0.1 & -0.2 & -0.1 & -0.2 & -0.4 & -0.3 & -0.5 & -0.1 & -0.4 & 0 \\
\hline hsa-mir-151a & -0.4 & 0 & 0.1 & 0 & -0.3 & -0.3 & -0.2 & -0.2 & -0.1 & -0.4 & -0.4 & -0.4 & -0.5 & -0.2 & -0.1 & 0 & 0 & -0.1 & -0.5 & -0.4 & -0.5 & -0.3 & -0.3 & 0 \\
\hline hsa-mir-3193 & 0.4 & 0.1 & 0.1 & 0 & -0.3 & -0.3 & -0.3 & -0.3 & -0.1 & -0.5 & -0.4 & -0.4 & -0.5 & -0.2 & -0.2 & 0 & -0.1 & -0.1 & -0.6 & -0.3 & -0.5 & -0.2 & -0.3 & 0 \\
\hline hsa-mir-183 & -0.4 & 0 & 0 & 0.1 & -0.3 & -0.3 & -0.2 & -0.3 & -0.4 & -0.5 & -0.4 & -0.4 & -0.5 & -0.3 & -0.2 & -0.2 & 0 & -0.1 & -0.4 & -0.3 & -0.5 & -0.2 & -0.5 & 0.1 \\
\hline hsa-mir-191 & 5 & 0 & -0.1 & 0.1 & -0.4 & -0.3 & -0.3 & -0.2 & -0.1 & -0.4 & -0.5 & -0.5 & -0.5 & -0.3 & -0.1 & 0.1 & 0 & 0 & -0.5 & -0.4 & -0.6 & -0.4 & -0.3 & .1 \\
\hline hsa-mir-141 & & 0 & 0.1 & 0.1 & -0.3 & -0.5 & -0.3 & -0.2 & -0.1 & -0.5 & -0.5 & -0.5 & -0.5 & -0.3 & -0.1 & 0.2 & 0 & 0 & -0.6 & -0.3 & -0.6 & -0.4 & -0.3 & 0.1 \\
\hline hsa-mir-7706 & .5 & 0 & -0.1 & 0 & -0.3 & -0.4 & -0.2 & -0.3 & -0.2 & -0.5 & -0.4 & -0.4 & -0.5 & -0.2 & -0.1 & 0 & 0 & -0.1 & -0.5 & -0.4 & -0.5 & -0.2 & -0.4 & 0 \\
\hline hsa-mir-200c & & 0.1 & 0.2 & 0.1 & -0.4 & -0.5 & -0.3 & -0.2 & -0.1 & -0.5 & -0.6 & -0.5 & -0.6 & -0.3 & -0.1 & 0.2 & 0 & 0 & -0.6 & -0.4 & -0.6 & -0.4 & -0.3 & 0.1 \\
\hline hsa-mir-429 & -0.5 & 0.1 & 0 & 0.1 & -0.4 & -0.3 & -0.3 & -0.3 & -0.2 & -0.5 & -0.5 & -0.6 & -0.6 & -0.3 & -0.1 & 0.1 & 0.1 & -0.1 & -0.5 & -0.5 & -0.7 & -0.4 & -0.3 & 0.1 \\
\hline hsa-mir-200b & 6 & 0.1 & 0 & 0.2 & -0.4 & -0.4 & -0.3 & -0.3 & -0.2 & -0.5 & -0.6 & -0.6 & -0.6 & -0.3 & -0.1 & 0.1 & 0.1 & 0 & -0.5 & -0.5 & $-0.7 \mid$ & -0.4 & -0.3 & 0.1 \\
\hline \multirow[t]{2}{*}{ hsa-mir-200a } & 6 & 0.1 & 0 & 0.1 & -0.4 & -0.4 & -0.3 & -0.3 & -0.2 & -0.5 & -0.6 & -0.6 & -0.6 & -0.3 & -0.1 & 0.1 & 0.1 & 0 & -0.5 & -0.4 & $|-0.7|$ & -0.4 & -0.4 & 0.1 \\
\hline & $\begin{array}{l}\stackrel{N}{Y} \\
\stackrel{U}{U}\end{array}$ & $\frac{Y}{\frac{Y}{4}}$ & 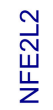 & $\frac{N}{\frac{N}{0}}$ & 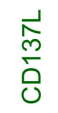 & $\begin{array}{l}\text { O } \\
\text { Oิ }\end{array}$ & $\begin{array}{l}\stackrel{0}{N} \\
\text { Oิ }\end{array}$ & $\begin{array}{l}\hat{N} \\
\text { Õ }\end{array}$ & $\begin{array}{l}\text { 巳 } \\
\text { Ơ }\end{array}$ & $\begin{array}{l}\infty \\
\stackrel{Ð}{\cup} \\
\text { U }\end{array}$ & $\begin{array}{l}\text { P } \\
\text { O }\end{array}$ & $\begin{array}{l}\text { ᄋ } \\
\text { Oे }\end{array}$ & $\begin{array}{l}0 \\
\infty \\
0\end{array}$ & $\frac{\overrightarrow{\underline{r}}}{\frac{\vec{E}}{0}}$ & 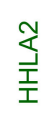 & $\underset{⿱ 亠}{\stackrel{\sum}{\boxplus}}$ & $\begin{array}{l}0 \\
\text { 凹 } \\
0 \\
0 \\
\underline{U}\end{array}$ & ৫) & $\begin{array}{l}\text { 뭉 } \\
\text { ○े }\end{array}$ & $\begin{array}{l}\overline{1} \\
1 \\
0 \\
0\end{array}$ & $\begin{array}{l}Y \\
1 \\
1 \\
0 \\
0\end{array}$ & $\stackrel{\underline{\alpha}}{\not}$ & $\frac{\overleftarrow{6}}{>}$ & Z \\
\hline
\end{tabular}

Figure 1. Heatmap showing negative correlations between selected genes active at cancer side of the immunological synapse: CD112, CD137L, CD200, CD276, CD277, CD40, CD48, CD70, CD80, CD86, GITRL, HHLA2, HVEM, ICOSLG, LGALS9, OX40L, PD-L1, PD-L2, PVR, VISTA and VTCN1, transcription factors: BACH2, MAFK and NFE2L2 and miRNA. Negative correlations are shown in blue. The numbers in heatmap tiles represent the correlation coefficients. The following statistical criteria were used to filter miRNA: correlation coefficient $<=-0.2$ for anticorrelated microRNAs and statistical significance of correlation ( $p$-value from cor.test function in $\mathrm{R})<0.01$.

We also obtained 19 miRNAs generally correlated with gene expression: mir-155, mir-146b, mir-142, mir-146a, mir-29a, mir-150, mir-4772, mir-5586, mir-223, mir-7702, mir-199b, mir-100, mir-199a-2, mir-511, mir-125b-1, mir-125b-2, mir-199a-1, mir-221 and mir-21 (Figure 2). In this case, it is more difficult to speculate if this positive correlation indicates indirect regulation or these miRNAs are generally upregulated in 
cancer alongside immune response genes and are responsible for different functions, for example suppressing an unrelated set of genes.

TCGA - BLCA: mRNA - miRNA correlations

$\mathrm{p}$-value $<0.01$ and mean $\mathrm{R}>0.2$
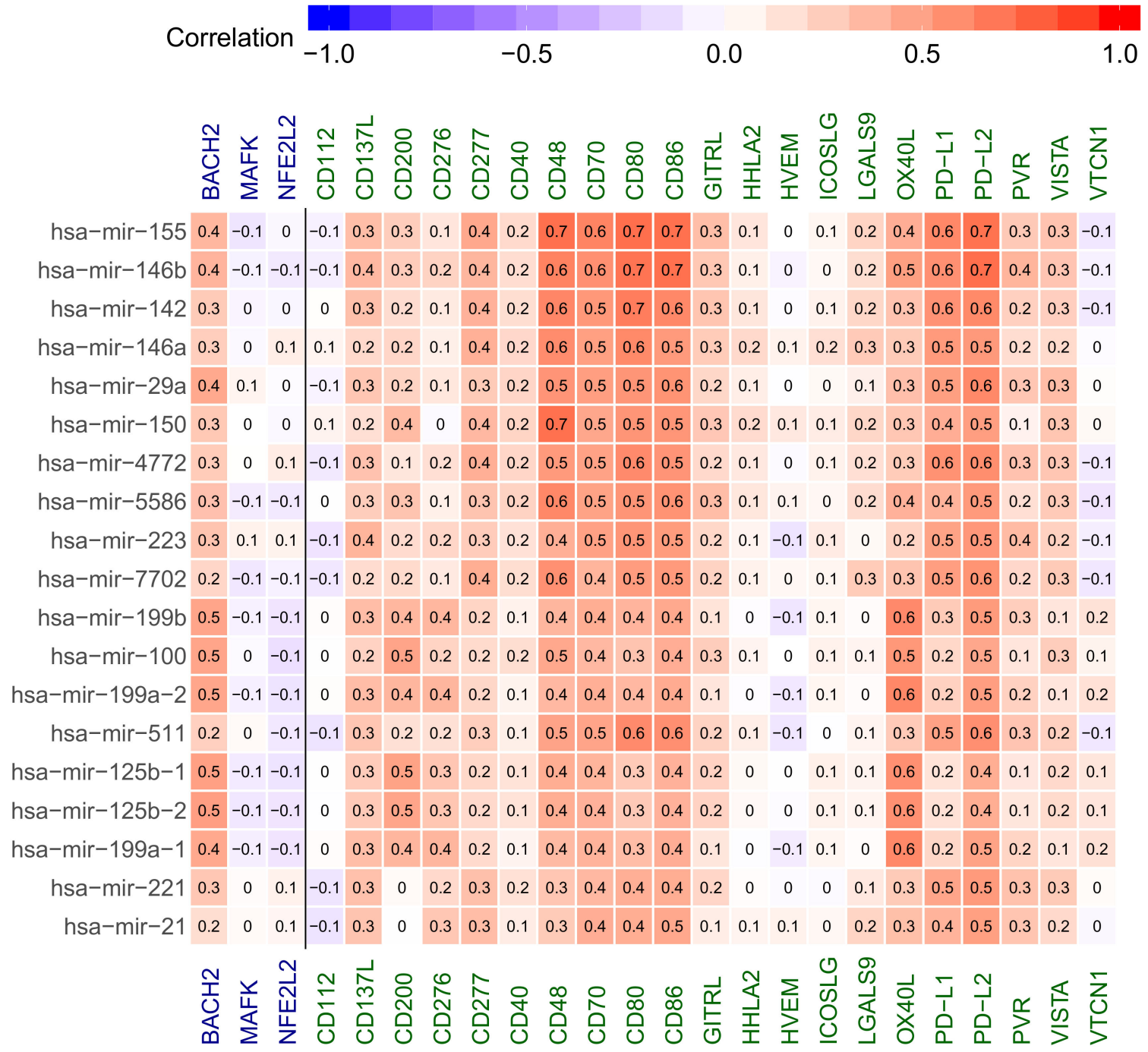

Figure 2. Heatmap showing positive correlations between selected genes active at cancer side of the immunological synapse: CD112, CD137L, CD200, CD276, CD277, CD40, CD48, CD70, CD80, CD86, GITRL, HHLA2, HVEM, ICOSLG, LGALS9, OX40L, PD-L1, PD-L2, PVR, VISTA and VTCN1, transcription factors: BACH2, MAFK and NFE2L2 and miRNA. Positive correlations are shown in red. The numbers in heatmap tiles represent the correlation coefficient. The following statistical criteria were used to filter miRNA: correlation coefficient $>=0.2$ for correlated microRNAs and statistical significance of correlation $(p$-value from cor.test function in $\mathrm{R})<0.01$.

\subsection{Correlations Analyses in Bladder Cancer Samples-Genes to Genes}

To better understand the impact of underlying gene regulatory network on genesmiRNA interactions, we analysed the correlations between the genes and transcription factors only. These created a symmetric correlation heatmap (Figure 3), which we further projected as a correlation-driven network using a force-directed layout (Figure 4). 
TCGA - BLCA: mRNA correlations

21 genes immunological synapse genes plus 3 transcription factors

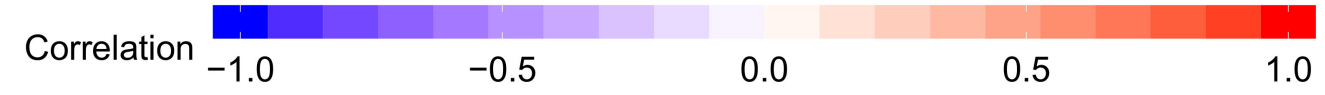

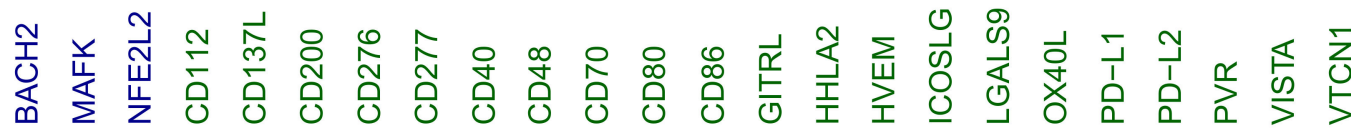

\begin{tabular}{|c|c|c|c|c|c|c|c|c|c|c|c|c|c|c|c|c|c|c|c|c|c|c|c|c|}
\hline $\mathrm{BACH} 2$ & 1 & -0.1 & 0 & 0.1 & 0.3 & 0.5 & 0.3 & 0.2 & 0.1 & 0.5 & 0.5 & 0.5 & 0.5 & 0.3 & 0.1 & -0.2 & 0 & 0 & 0.6 & 0.4 & 0.6 & 0.3 & 0.2 & 0 \\
\hline MAFK & .1 & 1 & 0.2 & 0.2 & 0 & 0 & -0.1 & 0.1 & 0 & -0.1 & -0.1 & 0 & -0.1 & 0 & -0.1 & 0 & 0.1 & -0.1 & -0.1 & 0 & -0.1 & 0.1 & 0.1 & 0.1 \\
\hline FE2L2 & 0 & 0.2 & 1 & 0.1 & 0 & -0.1 & 0 & 0.2 & 0.1 & 0 & 0 & 0 & 0 & 0 & 0.1 & 0 & 0.1 & 0.1 & -0.1 & 0 & -0.1 & -0.1 & 0 & 0.1 \\
\hline CD112 & 0.1 & 0.2 & 0.1 & 1 & 0 & 0.1 & -0.1 & 0.1 & 0 & 0 & 0 & 0 & -0.1 & 0.1 & 0 & 0.1 & 0 & 0 & 0.1 & -0.1 & -0.1 & -0.1 & -0.1 & 0.2 \\
\hline D137L & 0.3 & 0 & 0 & 0 & 1 & 0.1 & 0.3 & 0.1 & 0.1 & 0.3 & 0.6 & 0.4 & 0.4 & 0.3 & 0.1 & -0.1 & 0 & 0 & 0.4 & 0.3 & 0.4 & 0.3 & 0.1 & -0.1 \\
\hline CD200 & 0.5 & 0 & -0.1 & 0.1 & 0.1 & 1 & 0.2 & 0.2 & 0.2 & 0.5 & 0.3 & 0.4 & 0.4 & 0.4 & 0.1 & 0 & 0 & 0.1 & 0.6 & 0.2 & 0.4 & 0.1 & 0.2 & 0.1 \\
\hline CD276 & 0.3 & -0.1 & 0 & -0.1 & 0.3 & 0.2 & 1 & 0.2 & 0 & 0.2 & 0.3 & 0.2 & 0.3 & 0.2 & 0 & -0.2 & 0 & 0.1 & 0.4 & 0.2 & 0.4 & 0.3 & 0.1 & -0.1 \\
\hline CD277 & 0.2 & 0.1 & 0.2 & 0.1 & 0.1 & 0.2 & 0.2 & 1 & 0.4 & 0.5 & 0.4 & 0.5 & 0.5 & 0.2 & 0.2 & 0.3 & 0.1 & 0.5 & 0.4 & 0.5 & 0.5 & 0.1 & 0.3 & 0 \\
\hline CD4C & 0.1 & 0 & 0.1 & 0 & 0.1 & 0.2 & 0 & 0.4 & 1 & 0.4 & 0.3 & 0.3 & 0.3 & 0.2 & 0.2 & 0.5 & 0 & 0.4 & 0.2 & 0.2 & 0.3 & -0.1 & 0.3 & -0.2 \\
\hline CD48 & 0.5 & -0.1 & 0 & 0 & 0.3 & 0.5 & 0.2 & 0.5 & 0.4 & 1 & 0.6 & 0.8 & 0.8 & 0.4 & 0.2 & 0.2 & 0.1 & 0.4 & 0.6 & 0.6 & 0.8 & 0.2 & 0.5 & -0.1 \\
\hline CD7C & 0.5 & -0.1 & 0 & 0 & 0.6 & 0.3 & 0.3 & 0.4 & 0.3 & 0.6 & & 0.7 & 0.7 & 0.4 & 0.2 & 0 & 0.1 & 0.2 & 0.5 & 0.5 & 0.7 & 0.3 & 0.2 & -0.1 \\
\hline CD8C & 0.5 & 0 & 0 & 0 & 0.4 & 0 & 0.2 & 0.5 & 0.3 & 0.8 & 0.7 & 1 & 0.9 & 0.5 & 0.2 & 0 & 0 & 0.3 & 0.6 & 0.7 & 0.9 & 0.4 & 0.3 & -0.1 \\
\hline CD86 & 0.5 & 0.1 & 0 & -0.1 & 0.4 & 0 & 0.3 & 0.5 & 0.3 & 0.8 & 0.7 & .9 & & 0.5 & 0.2 & 0 & 0.1 & 0.3 & 0.6 & 0.6 & 0.8 & 0.3 & 0.4 & -0.1 \\
\hline GITR & 0.3 & 0 & 0 & 0.1 & 0.3 & 0.4 & 0.2 & 0.2 & 0.2 & 0.4 & 0.4 & 0.5 & 0.5 & & 0.2 & 0 & 0 & 0.1 & 0.5 & .3 & 0.4 & 0.2 & 0.2 & -0.1 \\
\hline $\mathrm{HHLA} 2$ & 0.1 & -0.1 & 0.1 & 0 & 0.1 & 0.1 & 0 & 0.2 & 0.2 & 0.2 & 0.2 & 0.2 & 0.2 & 0.2 & 1 & 0.1 & 0 & 0.1 & 0.1 & 0.1 & 0.1 & 0 & 0.1 & -0.1 \\
\hline HVEN & -0.2 & 0 & 0 & 0.1 & -0.1 & 0 & -0.2 & 0.3 & 0.5 & 0. & 0 & 0 & 0 & 0 & 0.1 & 1 & 0.1 & 0.5 & 0 & 0 & -0.1 & -0.3 & 0.3 & -0.1 \\
\hline ICOSLC & 0 & 0.1 & 0 & 0 & 0 & 0 & 0 & 0.1 & 0 & 0.1 & 1 & 0 & 0. & 0 & 0 & 0.1 & 1 & 0.2 & 0 & c & 0 & -0.1 & 0 & 0.1 \\
\hline LGALS & 0 & -0.1 & 0 & 0 & 0 & 0 & 0.1 & 0.5 & 0.4 & 0.4 & 0.2 & 0.3 & 0.3 & 0.1 & 0.1 & 0.5 & 0.2 & 1 & 0.1 & 0.3 & 0.2 & -0.2 & 0.3 & 0 \\
\hline OX40L & 0.6 & -0.1 & -0.1 & 0.1 & 0.4 & 0. & 0.4 & 0.4 & 0.2 & 0.6 & 0.5 & 0.6 & 0.6 & .5 & 0.1 & 0 & 0 & 0.1 & 1 & 0.4 & 0.7 & 0.3 & 0.3 & 0.1 \\
\hline PD-L1 & 0.4 & 0 & 0 & -0.1 & 0.3 & 0 & 0.2 & 0.5 & 0.2 & 0.6 & 0.5 & 0.7 & 0.6 & 3 & 0.1 & 0 & 0 & 0.3 & 0.4 & & 0.8 & 0.4 & 0.3 & -0.1 \\
\hline PD-L2 & 0.6 & -0.1 & -0.1 & -0.1 & 0 & 0 & 0.4 & 0.5 & 0.3 & 0.8 & 0.7 & 0.9 & 0.8 & 0.4 & 0.1 & -0.1 & 0 & 0.2 & 0.7 & 0.8 & 1 & 0.5 & 0.4 & 0 \\
\hline PVR & 0.3 & 0.1 & -0.1 & -0.1 & 0.3 & 0.1 & 0.3 & 0.1 & -0.1 & 0.2 & 0.3 & 0.4 & 0.3 & 0.2 & 0 & -0.3 & -0.1 & -0.2 & 0.3 & 0.4 & 0.5 & 1 & 0.1 & -0.1 \\
\hline VIST/ & 0.2 & 0.1 & 0 & -0.1 & 0 & 0.2 & 0.1 & 0.3 & 0.3 & 0.5 & 0.2 & 0.3 & 0.4 & 0.2 & 0.1 & 0.3 & 0 & 0.3 & 0.3 & 0.3 & 0.4 & 0.1 & & $-c$ \\
\hline VTCN1 & 0 & 0.1 & 0.1 & 0.2 & -0.1 & 0.1 & -0.1 & 0 & -0.2 & -0.1 & -0.1 & -0.1 & -0.1 & -0.1 & -0.1 & -0.1 & 0.1 & 0 & 0.1 & -0.1 & 0 & -0.1 & -0.1 & \\
\hline & 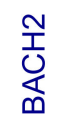 & 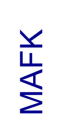 & 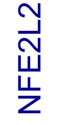 & $\frac{\stackrel{N}{\frac{\sigma}{0}}}{\frac{1}{0}}$ & $\frac{\sqrt{n}}{\stackrel{m}{0}}$ & $\begin{array}{l}\text { ̊․ } \\
\text { Oิ }\end{array}$ & 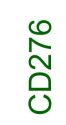 & 仓ิ & $\begin{array}{l}\text { 웜 } \\
\text { Oे }\end{array}$ & $\begin{array}{l}\infty \\
\text { ป }\end{array}$ & $\begin{array}{l}\text { ㅇ } \\
\text { Oด }\end{array}$ & $\begin{array}{l}0 \\
\infty \\
0\end{array}$ & $\begin{array}{l}0 \\
\stackrel{0}{0} \\
\text { O }\end{array}$ & $\frac{\overrightarrow{\widetilde{Y}}}{\overline{0}}$ & 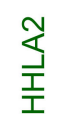 & $\underset{\text { ㅍ }}{\stackrel{\text { I }}{\gtrless}}$ & $\begin{array}{l}\text { O } \\
\text { ஸ口 } \\
\text { Oુ }\end{array}$ & 㣽 & 芒 & $\begin{array}{l}\overline{1} \\
0 \\
0\end{array}$ & $\begin{array}{l}\text { Y } \\
1 \\
0 \\
0\end{array}$ & $\stackrel{\Upsilon}{\stackrel{\alpha}{\alpha}}$ & $\stackrel{\frac{1}{6}}{\stackrel{5}{>}}$ & $\begin{array}{l}3 \\
0 \\
5\end{array}$ \\
\hline
\end{tabular}

Figure 3. Heatmap showing correlations between selected genes active at cancer side of the immunological synapse: CD112, CD137L, CD200, CD276, CD277, CD40, CD48, CD70, CD80, CD86, GITRL, HHLA2, HVEM, ICOSLG, LGALS9, OX40L, PD-L1, PD-L2, PVR, VISTA and VTCN1, transcription factors: BACH2, MAFK and NFE2L2. Positive correlations are shown in red, negative correlations are shown in blue. The numbers in heatmap tiles represent the correlation coefficients. 
- Checkpoint genes

- TFs

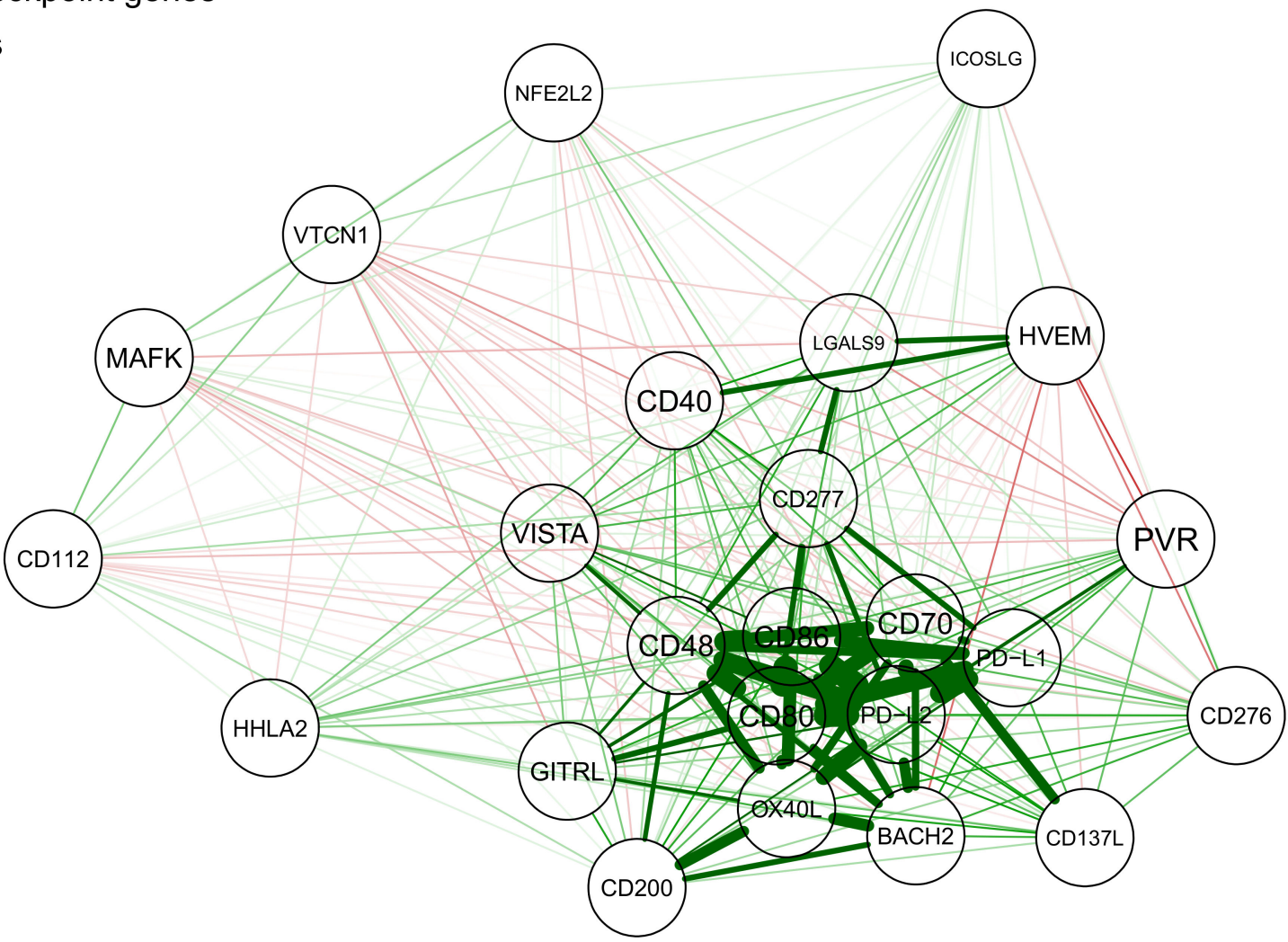

Figure 4. Expression correlation network showing genes active at cancer side of the immunological synapse (red nodes): CD112, CD137L, CD200, CD276, CD277, CD40, CD48, CD70, CD80, CD86, GITRL, HHLA2, HVEM, ICOSLG, LGALS9, OX40L, PD-L1, PD-L2, PVR, VISTA and VTCN1 and transcription factors (blue nodes): BACH2, MAFK and NFE2L2. Green lines represent positive correlations, and red lines represent negative ones. Line thickness represents the strength of the correlation.

The genes that we previously observed to be well-correlated and anticorrelated to miRNA hits, CD48 CD70 CD80 CD86 OX40L PD-L1 PD-L2, show a good correlation with each other resulting in a distinctive cluster (Figure 4). Additionally, the BACH2 transcription factor is well-corelated to genes within this group. Other genes are either not that strongly correlated, or strongly correlated only to a single gene within the cluster, rather than forming further cliques.

\subsection{Correlations Analyses in Bladder Cancer Samples—miRNA to miRNA}

To investigate if gene-miRNA interaction is influenced by a specific pattern of correlations between miRNAs themselves, we analysed the correlations within previously identified miRNA hits. Figures 5 and 6 show correlations within negatively and positively correlated miRNA hits, respectively. We also projected these correlations on the common interaction network using a force-directed layout (Figure 7).

As expected, both groups of miRNAs were well-correlated within each set, with the correlation of 1 or close to one for miRNAs leading to the same mature microRNA. However, we observed some examples of nearly identical expression profiles between different miRNAs, for example, hsa-mir-429, hsa-mir-200b and hsa-mir-200a in negative hits; and hsa - mir $-199 \mathrm{~b}$, hsa - mir -100 , hsa - mir $-199 a-2$, hsa - mir $-125 b-1$ and hsa - mir $-125 \mathrm{~b}-2 \mathrm{hsa}-\mathrm{mir}-199 \mathrm{a}-1$ in positive hits. 
TCGA - BLCA: miRNA correlations

microRNAs negatively correlated with immunological synapse genes
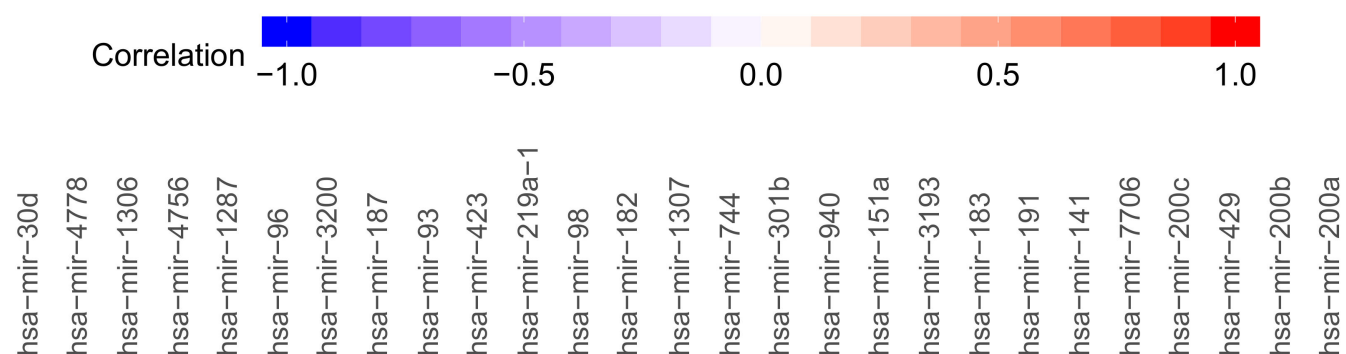

hsa-mir-30d

hsa-mir-4778

hsa-mir-1306

hsa-mir-4756

hsa-mir-1287

hsa-mir-96

hsa-mir-3200

hsa-mir-187

hsa-mir-93

hsa-mir-423

hsa-mir-219a-1

1

\begin{tabular}{|l|l|l|l|l|l|l|l|l|l|l|l|l|l|l|l|l|l|l|l|l|l|l|l|l|l|}
0.4 & 0.4 & 0.4 & 0.5 & 0.4 & 0.3 & 0.3 & 0.5 & 0.4 & 0.4 & 0.5 & 0.5 & 0.4 & 0.4 & 0.3 & 0.3 & 0.6 & 0.4 & 0.4 & 0.6 & 0.5 & 0.5 & 0.6 & 0.5 & 0.6 & 0.6 \\
\hline
\end{tabular}

\begin{tabular}{|l|l|l|l|l|l|l|l|l|l|l|l|l|l|l|l|l|l|l|l|l|l|l|l|l|l|l|}
\hline 0.4 & 1 & 0.3 & 0.4 & 0.4 & 0.4 & 0.3 & 0.5 & 0.4 & 0.4 & 0.4 & 0.4 & 0.4 & 0.4 & 0.3 & 0.3 & 0.4 & 0.4 & 0.3 & 0.4 & 0.5 & 0.5 & 0.3 & 0.5 & 0.6 & 0.5 & 0.5 \\
\hline
\end{tabular}

\begin{tabular}{|l|l|l|l|l|l|l|l|l|l|l|l|l|l|l|l|l|l|l|l|l|l|l|l|l|l|l|}
\hline 0.4 & 0.3 & 1 & 0.2 & 0.5 & 0.4 & 0.6 & 0.3 & 0.6 & 0.7 & 0.5 & 0.5 & 0.4 & 0.7 & 0.7 & 0.7 & 0.7 & 0.6 & 0.4 & 0.5 & 0.5 & 0.4 & 0.6 & 0.4 & 0.5 & 0.4 & 0.5 \\
\hline
\end{tabular}

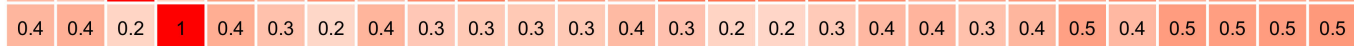

\begin{tabular}{|l|l|l|l|l|l|l|l|l|l|l|l|l|l|l|l|l|l|l|l|l|l|l|l|l|l|l|}
\hline 0.5 & 0.4 & 0.5 & 0.4 & 1 & 0.4 & 0.4 & 0.4 & 0.4 & 0.4 & 0.4 & 0.4 & 0.4 & 0.5 & 0.5 & 0.5 & 0.5 & 0.6 & 0.5 & 0.4 & 0.5 & 0.5 & 0.5 & 0.5 & 0.5 & 0.6 & 0.5 \\
\hline
\end{tabular}

\begin{tabular}{|l|l|l|l|l|l|l|l|l|l|l|l|l|l|l|l|l|l|l|l|l|l|l|l|l|l|l|}
\hline 0.4 & 0.4 & 0.4 & 0.3 & 0.4 & 1 & 0.4 & 0.3 & 0.6 & 0.6 & 0.5 & 0.5 & 0.9 & 0.5 & 0.4 & 0.5 & 0.4 & 0.4 & 0.3 & 0.8 & 0.6 & 0.7 & 0.5 & 0.6 & 0.6 & 0.6 & 0.6 \\
\hline
\end{tabular}

\begin{tabular}{|l|l|l|l|l|l|l|l|l|l|l|l|l|l|l|l|l|l|l|l|l|l|l|l|l|l|l|}
\hline 0.3 & 0.3 & 0.6 & 0.2 & 0.4 & 0.4 & 1 & 0.3 & 0.6 & 0.6 & 0.4 & 0.4 & 0.4 & 0.5 & 0.5 & 0.6 & 0.5 & 0.4 & 0.4 & 0.5 & 0.5 & 0.4 & 0.6 & 0.5 & 0.5 & 0.4 & 0.5 \\
\hline
\end{tabular}

\begin{tabular}{|l|l|l|l|l|l|l|l|l|l|l|l|l|l|l|l|l|l|l|l|l|l|l|l|l|l|l|}
0.3 & 0.5 & 0.3 & 0.4 & 0.4 & 0.3 & 0.3 & 1 & 0.4 & 0.5 & 0.4 & 0.4 & 0.3 & 0.4 & 0.3 & 0.4 & 0.5 & 0.4 & 0.4 & 0.4 & 0.5 & 0.5 & 0.4 & 0.5 & 0.6 & 0.5 & 0.5 \\
\hline
\end{tabular}

\begin{tabular}{|l|l|l|l|l|l|l|l|l|l|l|l|l|l|l|l|l|l|l|l|l|l|l|l|l|l|l|}
\hline 0.5 & 0.4 & 0.6 & 0.3 & 0.4 & 0.6 & 0.6 & 0.4 & 1 & 0.7 & 0.6 & 0.5 & 0.6 & 0.7 & 0.5 & 0.7 & 0.4 & 0.4 & 0.3 & 0.6 & 0.7 & 0.6 & 0.6 & 0.6 & 0.6 & 0.6 & 0.6 \\
\hline
\end{tabular}

\begin{tabular}{|l|l|l|l|l|l|l|l|l|l|l|l|l|l|l|l|l|l|l|l|l|l|l|l|l|l|l|}
\hline 0.4 & 0.4 & 0.7 & 0.3 & 0.4 & 0.6 & 0.6 & 0.5 & 0.7 & 1 & 0.6 & 0.6 & 0.5 & 0.7 & 0.6 & 0.6 & 0.6 & 0.5 & 0.5 & 0.5 & 0.7 & 0.7 & 0.6 & 0.6 & 0.6 & 0.6 & 0.6 \\
\hline
\end{tabular}

\begin{tabular}{|l|l|l|l|l|l|l|l|l|l|l|l|l|l|l|l|l|l|l|l|l|l|l|l|l|l|l|}
0.4 & 0.4 & 0.5 & 0.3 & 0.4 & 0.5 & 0.4 & 0.4 & 0.6 & 0.6 & 1 & 0.4 & 0.4 & 0.6 & 0.5 & 0.5 & 0.4 & 0.4 & 0.4 & 0.5 & 0.5 & 0.6 & 0.5 & 0.5 & 0.5 & 0.5 & 0.5 \\
\hline
\end{tabular}

hsa-mir-98

\begin{tabular}{|l|l|l|l|l|l|l|l|l|l|l|l|l|l|l|l|l|l|l|l|l|l|l|l|l|l|l|}
0.5 & 0.4 & 0.5 & 0.3 & 0.4 & 0.5 & 0.4 & 0.4 & 0.5 & 0.6 & 0.4 & 1 & 0.5 & 0.5 & 0.6 & 0.6 & 0.6 & 0.6 & 0.4 & 0.6 & 0.5 & 0.4 & 0.6 & 0.5 & 0.6 & 0.5 & 0.5 \\
\hline
\end{tabular}

hsa-mir-182

\begin{tabular}{|l|l|l|l|l|l|l|l|l|l|l|l|l|l|l|l|l|l|l|l|l|l|l|l|l|l|l|}
0.5 & 0.4 & 0.4 & 0.4 & 0.4 & 0.9 & 0.4 & 0.3 & 0.6 & 0.5 & 0.4 & 0.5 & 1 & 0.5 & 0.4 & 0.4 & 0.4 & 0.5 & 0.4 & 0.9 & 0.6 & 0.6 & 0.5 & 0.7 & 0.6 & 0.6 & 0.6 \\
\hline
\end{tabular}

hsa-mir-1307 \begin{tabular}{|l|l|l|l|l|l|l|l|l|l|l|l|l|l|l|l|l|l|l|l|l|l|l|l|l|l|l}
0.4 & 0.4 & 0.7 & 0.3 & 0.5 & 0.5 & 0.5 & 0.4 & 0.7 & 0.7 & 0.6 & 0.5 & 0.5 & 1 & 0.7 & 0.6 & 0.6 & 0.6 & 0.5 & 0.6 & 0.6 & 0.6 & 0.7 & 0.6 & 0.6 & 0.5 & 0.6 \\
\hline
\end{tabular}

hsa-mir-744 \begin{tabular}{|l|l|l|l|l|l|l|l|l|l|l|l|l|l|l|l|l|l|l|l|l|l|l|l|l|l|l|}
0.4 & 0.3 & 0.7 & 0.2 & 0.5 & 0.4 & 0.5 & 0.3 & 0.5 & 0.6 & 0.5 & 0.6 & 0.4 & 0.7 & 1 & 0.6 & 0.7 & 0.6 & 0.4 & 0.5 & 0.5 & 0.4 & 0.6 & 0.4 & 0.5 & 0.5 & 0.5 \\
\hline
\end{tabular}

hsa-mir-301b \begin{tabular}{|l|l|l|l|l|l|l|l|l|l|l|l|l|l|l|l|l|l|l|l|l|l|l|l|l|l|l|}
0.3 & 0.3 & 0.7 & 0.2 & 0.5 & 0.5 & 0.6 & 0.4 & 0.7 & 0.6 & 0.5 & 0.6 & 0.4 & 0.6 & 0.6 & 1 & 0.6 & 0.4 & 0.4 & 0.6 & 0.6 & 0.5 & 0.6 & 0.4 & 0.6 & 0.5 & 0.5 \\
\hline
\end{tabular}

hsa-mir-940 \begin{tabular}{|l|l|l|l|l|l|l|l|l|l|l|l|l|l|l|l|l|l|l|l|l|l|l|l|l|l|l|}
0.3 & 0.4 & 0.7 & 0.3 & 0.5 & 0.4 & 0.5 & 0.5 & 0.4 & 0.6 & 0.4 & 0.6 & 0.4 & 0.6 & 0.7 & 0.6 & 1 & 0.6 & 0.4 & 0.6 & 0.5 & 0.4 & 0.5 & 0.4 & 0.5 & 0.5 & 0.5 \\
\hline
\end{tabular}

hsa-mir-151a \begin{tabular}{|l|l|l|l|l|l|l|l|l|l|l|l|l|l|l|l|l|}
\hline 0.6 & 0.4 & 0.6 & 0.4 & 0.6 & 0.4 & 0.4 & 0.4 & 0.4 & 0.5 & 0.4 & 0.6 & 0.5 & 0.6 & 0.6 & 0.4 & 0.6 \\
\hline
\end{tabular} \begin{tabular}{l|l|l|l|l|l|l|l|l|l|}
\hline 1 & 0.5 & 0.5 & 0.5 & 0.5 & 0.6 & 0.6 & 0.6 & 0.6 & 0.6 \\
\hline
\end{tabular}

hsa-mir-3193 \begin{tabular}{|l|l|l|l|l|l|l|l|l|l|l|l|l|l|l|l|l|l|l|l|l|l|l|l|l|l|l|}
0.4 & 0.3 & 0.4 & 0.4 & 0.5 & 0.3 & 0.4 & 0.4 & 0.3 & 0.5 & 0.4 & 0.4 & 0.4 & 0.5 & 0.4 & 0.4 & 0.4 & 0.5 & 1 & 0.4 & 0.4 & 0.5 & 0.5 & 0.5 & 0.4 & 0.5 & 0.5 \\
\hline
\end{tabular}

hsa-mir-183 \begin{tabular}{|l|l|l|l|l|l|l|l|l|l|l|l|l|l|l|l|l|l|l|l|l|l|l|l|l|l|l|}
\hline 0.4 & 0.4 & 0.5 & 0.3 & 0.4 & 0.8 & 0.5 & 0.4 & 0.6 & 0.5 & 0.5 & 0.6 & 0.9 & 0.6 & 0.5 & 0.6 & 0.6 & 0.5 & 0.4 & 1 & 0.6 & 0.6 & 0.6 & 0.6 & 0.6 & 0.6 & 0.6 \\
\hline
\end{tabular}

hsa-mir-191 \begin{tabular}{|l|l|l|l|l|l|l|l|l|l|l|l|l|l|l|l|l|l|l|l|l|l|l|l|l|l|l|}
\hline 0.6 & 0.5 & 0.5 & 0.4 & 0.5 & 0.6 & 0.5 & 0.5 & 0.7 & 0.7 & 0.5 & 0.5 & 0.6 & 0.6 & 0.5 & 0.6 & 0.5 & 0.5 & 0.4 & 0.6 & 1 & 0.7 & 0.6 & 0.7 & 0.7 & 0.7 & 0.7 \\
\hline
\end{tabular}

hsa-mir-141 \begin{tabular}{|l|l|l|l|l|l|l|l|l|l|l|l|l|l|l|l|l|l|l|l|l|l|l|l|l|l|l|}
\hline 0.5 & 0.5 & 0.4 & 0.5 & 0.5 & 0.7 & 0.4 & 0.5 & 0.6 & 0.7 & 0.6 & 0.4 & 0.6 & 0.6 & 0.4 & 0.5 & 0.4 & 0.5 & 0.5 & 0.6 & 0.7 & 1 & 0.6 & 0.9 & 0.7 & 0.8 & 0.8 \\
\hline
\end{tabular}

hsa-mir-7706 \begin{tabular}{|l|l|l|l|l|l|l|l|l|l|l|l|l|l|l|l|l|l|l|l|l|l|l|l|l|l|l|}
0.5 & 0.3 & 0.6 & 0.4 & 0.5 & 0.5 & 0.6 & 0.4 & 0.6 & 0.6 & 0.5 & 0.6 & 0.5 & 0.7 & 0.6 & 0.6 & 0.5 & 0.6 & 0.5 & 0.6 & 0.6 & 0.6 & 1 & 0.6 & 0.6 & 0.6 & 0.6 \\
\hline
\end{tabular}

hsa-mir-200c \begin{tabular}{|l|l|l|l|l|l|l|l|l|l|l|l|l|l|l|l|l|l|l|l|l|l|l|l|l|l|l|}
0.6 & 0.5 & 0.4 & 0.5 & 0.5 & 0.6 & 0.5 & 0.5 & 0.6 & 0.6 & 0.5 & 0.5 & 0.7 & 0.6 & 0.4 & 0.4 & 0.4 & 0.6 & 0.5 & 0.6 & 0.7 & 0.9 & 0.6 & 1 & 0.7 & 0.8 & 0.8 \\
\hline
\end{tabular}

hsa-mir -429 \begin{tabular}{|l|l|l|l|l|l|l|l|l|l|l|l|l|l|l|l|l|l|l|l|l|l|l|l|l|l|l|}
0.5 & 0.6 & 0.5 & 0.5 & 0.5 & 0.6 & 0.5 & 0.6 & 0.6 & 0.6 & 0.5 & 0.6 & 0.6 & 0.6 & 0.5 & 0.6 & 0.5 & 0.6 & 0.4 & 0.6 & 0.7 & 0.7 & 0.6 & 0.7 & 1 & 1 & 0.9 \\
\hline
\end{tabular}

hsa-mir-200b \begin{tabular}{|l|l|l|l|l|l|l|l|l|l|l|l|l|l|l|l|l|l|l|l|l|l|l|l|l|}
0.6 & 0.5 & 0.4 & 0.5 & 0.6 & 0.6 & 0.4 & 0.5 & 0.6 & 0.6 & 0.5 & 0.5 & 0.6 & 0.5 & 0.5 & 0.5 & 0.5 & 0.6 & 0.5 & 0.6 & 0.7 & 0.8 & 0.6 & 0.8 & 1 \\
\hline
\end{tabular}

hsa-mir-200a \begin{tabular}{|l|l|l|l|l|l|l|l|l|l|l|l|l|l|l|l|l|l|l|l|l|l|l|l|l|l|l|}
\hline 0.6 & 0.5 & 0.5 & 0.5 & 0.5 & 0.6 & 0.5 & 0.5 & 0.6 & 0.6 & 0.5 & 0.5 & 0.6 & 0.6 & 0.5 & 0.5 & 0.5 & 0.6 & 0.5 & 0.6 & 0.7 & 0.8 & 0.6 & 0.8 & 0.9 & 1 & 1 \\
\hline
\end{tabular}

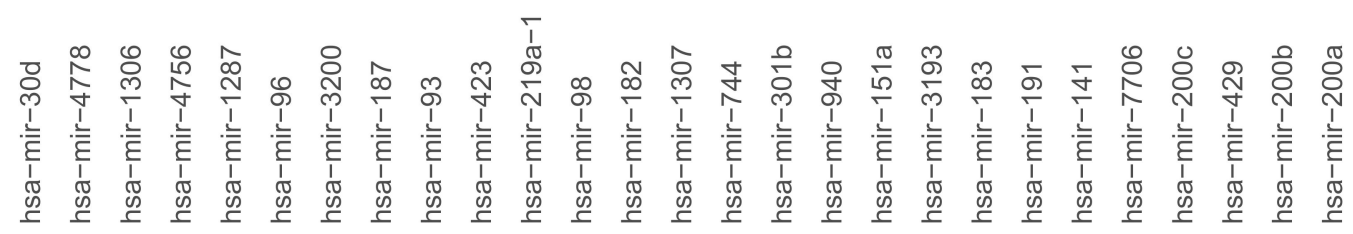

Figure 5. Heatmap showing correlations within miRNA hits negatively correlated to checkpoint genes. Positive correlations are shown in red, negative correlations are shown in blue. The numbers in heatmap tiles represent the correlation coefficients. 


\section{TCGA - BLCA: miRNA correlations}

microRNAs positively correlated with immunological synapse genes

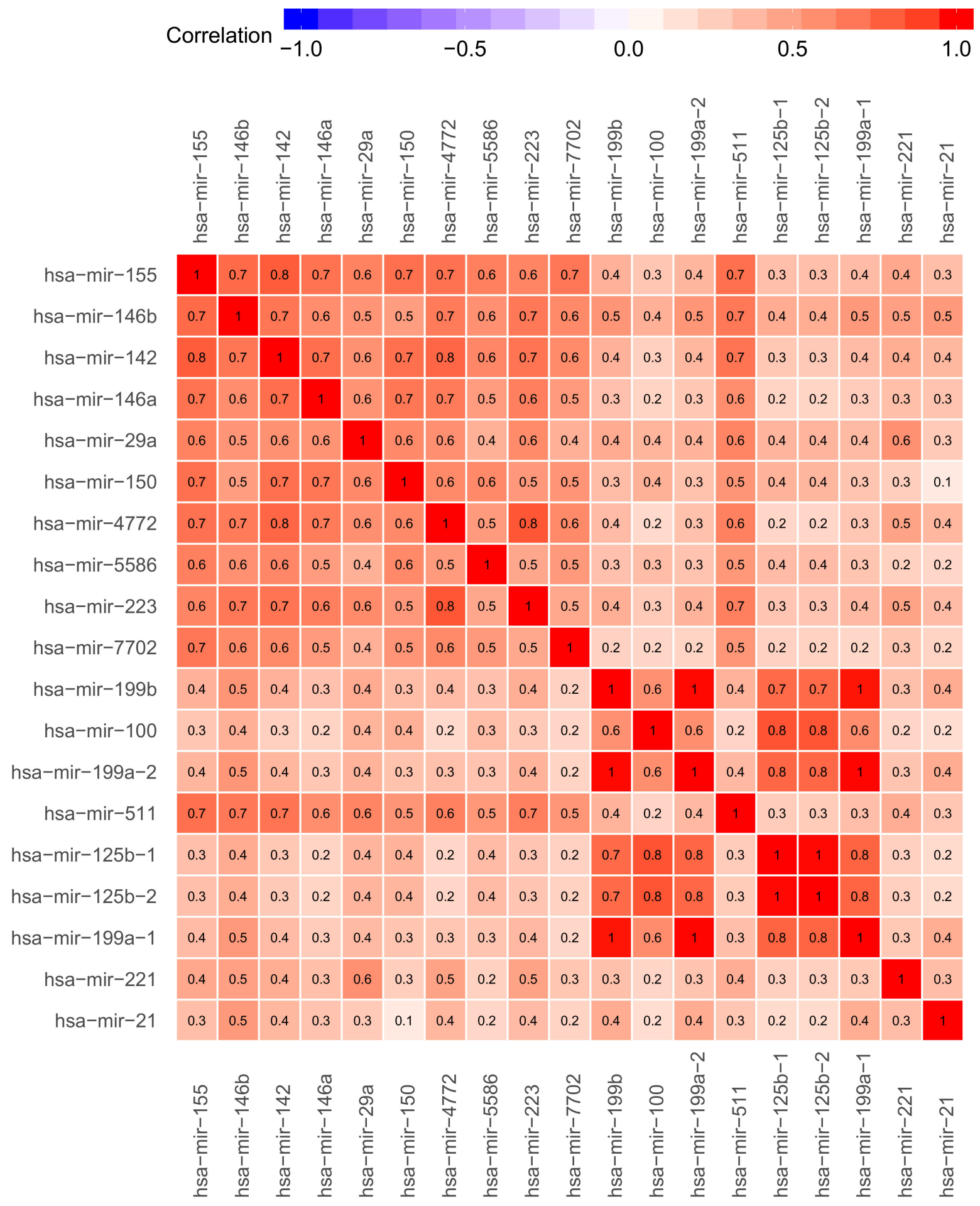

Figure 6. Heatmap showing correlations within miRNA hits positively correlated to checkpoint genes. Positive correlations are shown in red, negative correlations are shown in blue. The numbers in heatmap tiles represent the correlation coefficients. 
- miRNA [-]

- $\operatorname{miRNA}[+]$

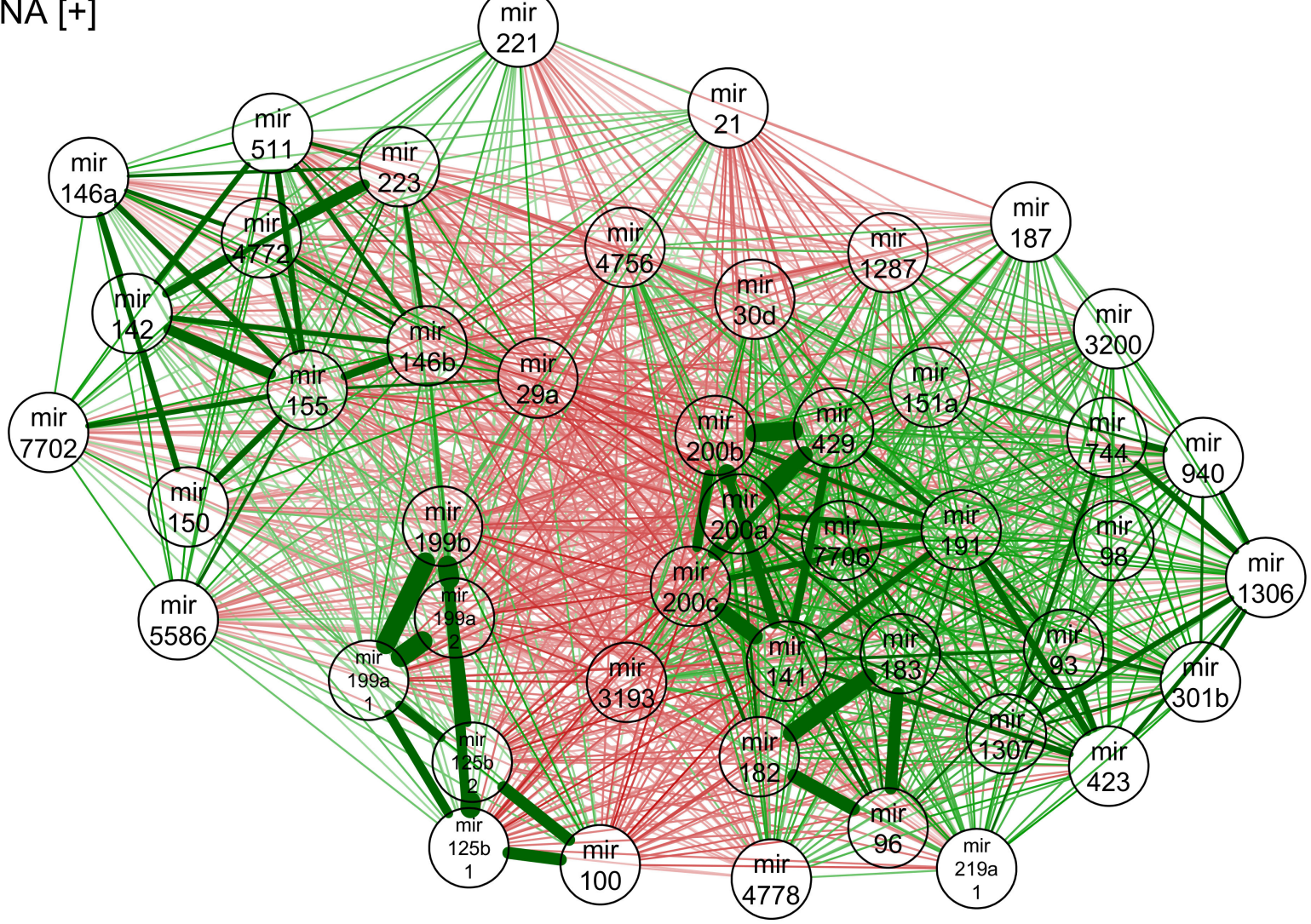

Figure 7. Expression correlation network showing positive (blue negative) and negative (red negative) miRNA hits. Green lines represent positive correlations and red lines represent negative ones. Line thickness represents the strength of the correlation.

When visualised as a network, correlations within miRNA targets showed similar expression profiles within positive and negative hit groups. Between these two groups, correlations were negative indicating — as expected—opposite expression patterns. Interestingly, we observed a further sub-clustering within both groups. Positive hits formed two distinct clusters, while negative hits formed two smaller, tightly correlated cliques with other miRNAs more loosely correlated.

\subsection{Network of Correlation Derived Interactions between miRNAs, Checkpoint Genes and TFs}

We analysed all the dependencies and possible interactions between miRNAs, checkpoint genes and TFs. We visualised them and a combined correlation network. Figure 8 shows the features we discovered in previous steps in a broader context. The gene cluster of CD48, CD70, CD80, CD86, OX40L, PD-L1, PD-L2 and BACH2 transcription factor is well-connected and visible in between positive and negative miRNA hits territories. Negative hits show well-connected cliques, that are also better anti-correlated with the cluster of checkpoint genes. Positive miRNA hits show two bigger, distinct clusters, of which one is more strongly correlated to the cluster of checkpoint genes. 
- Checkpoint genes

- miRNA [-]

- $\operatorname{miRNA}[+]$

- TFs

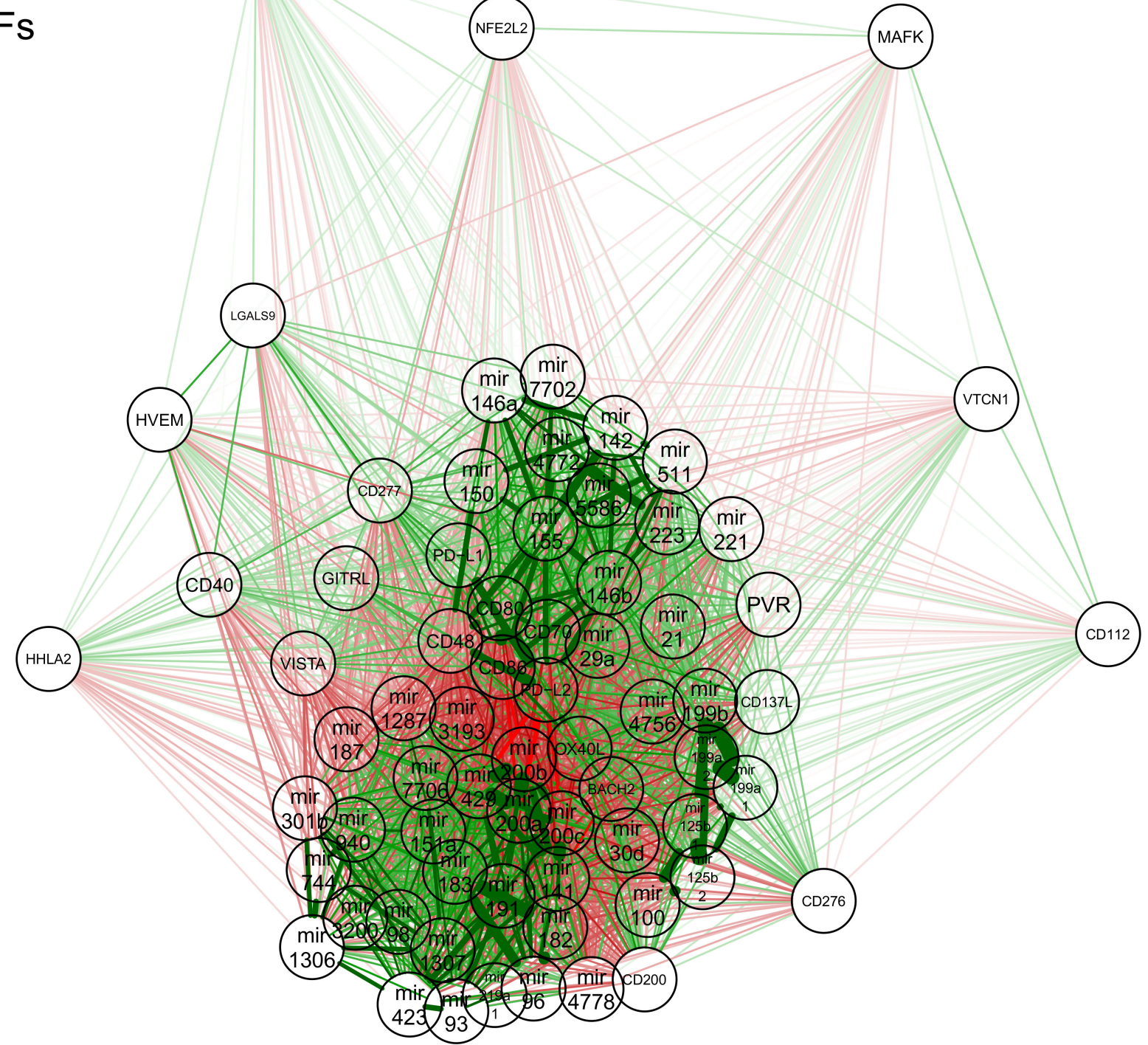

Figure 8. Combined expression correlation network showing negative (green nodes) and positive (blue nodes) miRNAs hits; immunological checkpoint genes (red nodes): CD112, CD137L, CD200, CD276, CD277, CD40, CD48, CD70, CD80, CD86, GITRL, HHLA2, HVEM, ICOSLG, LGALS9, OX40L, PD-L1, PD-L2, PVR, VISTA and VTCN1; and transcription factors (purple nodes): BACH2, MAFK and NFE2L2. Green lines represent positive correlations and red lines represent negative ones. Line thickness represents the strength of the correlation.

\subsection{Immune Synapse Genes Are Deregulated in Breast Cancer}

Finally, we analysed how the expression of the immune synapse gene set changes between cancer sample and normal tissue. It should be noted that this study is severely limited since cancer tissue data set in TCGA are much more numerous than normal tissue 414 and 19 samples, respectively. We obtained gene expression value estimates as fragments per million reads per kilobase of transcript (FPKM) and visualised their distributions with imposed box statistics in Figure 9. Direct comparison of FPKM distributions show us that all three transcription factors: BACH2, MAFK and NFE2L2 are downregulated in cancer cells. CD48, CD200 and VISTA are also downregulated in cancer samples, while CD276, LGALS9 and PVR are upregulated in cancer tissue. To understand these changes in the 
context of global expression, we have run differential expression analyses using the DEseq2 package. Taking into account a global dispersion and values of the expression, DEseq found MAFK, NFE2L2, CD200, CD80, HHLA2, LGALS9, PD-L1 (CD274) and PVR to be significantly upregulated, while CD112 (PVRIG), CD276, CD48 and VISTA (VSIR) are significantly downregulated. It should be noted that as with the very low expression values, such as $\mathrm{BACH} 2$, they are not assigned as significantly deregulated. However, analysing the distributions of the expression of $\mathrm{BACH} 2$ in cancer vs. normal tissue we see a small but significant difference.

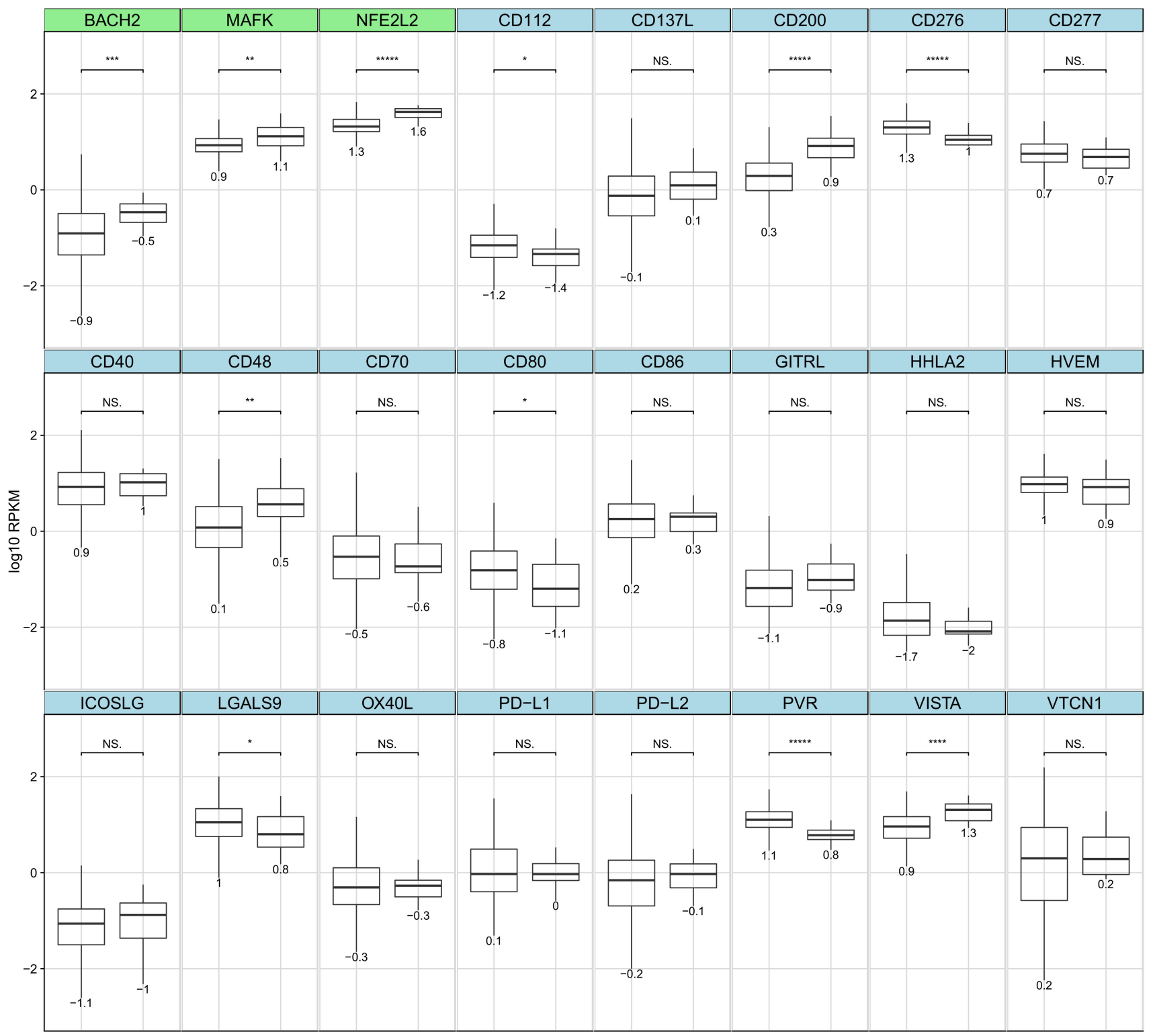

帛 Cancer tissue [414] 帛 Normal tissue [19]

Figure 9. Comparison of gene expression values in cancer vs. normal tissue. Visualised values represent fragments per million reads per kilobase of transcript (FPKM) obtained from TCGA. Violin plots show the distribution of expression values, with imposed boxplots visualising box statistics. A value below the violin plot denotes the median of the sample. The stars above each group indicate the significance level ( $p$-value) derived from Mann-Whitney (Wilcoxon) U test. $p$-value mapping go as follows: ${ }^{* * * *}$ represents a $p$-value below $0.00001,{ }^{* * * *}$ represents a $p$-value below $0.0001,{ }^{* * *}$ represents a $p$-value below $0.001,{ }^{* *}$ represents a $p$-value below 0.01 and * represents a $p$-value below 0.1 ; “NS." denotes not significant. 


\section{Discussion}

It has been suggested that bladder cancer should not be divided merely based on the characteristic of muscle invasion, thus generating two groups: muscle-invasive (MIBC, around $20 \%$ of bladder cancers at diagnosis) vs muscle-non-invasive (NMIBC, over $60 \%$ at diagnosis), based on the mutations they possess [12]. Both types have been studied extensively and it is clear that they differ genetically; for example, NMIBC has significantly fewer genomic rearrangements and mutations, whereas MIBC is characterised by frequent chromothripsis events, leading to many different aberrations [12]. Thus, currently, it is accepted that two types of bladder cancer mentioned above have several subgroups, still under investigation. It is clear if miRNAs can be used as biomarkers for these subgroups. Interestingly, most of the miRNAs analysed and described here were not previously reported to be involved in immunological synapse genes regulation. However, they were well connected with oncogenesis or cancer invasion events, as well as cancer's response to the therapeutics.

\subsection{The Most Positively Correlated miRNAs}

The top hit in correlated miRNAs, mir-155, is a known oncogenic microRNA that targets the ELK3 transcription factor that is imperative in the response to hypoxia [17]. It was shown to be upregulated in breast cancer and linked to PARP-1 inhibitors response [18]. In bladder cancer, this miR is known to be significantly overexpressed, promoting tumour growth by repressing DMTF1, a tumour-supressing gene [19].

The second-best hit, miR-146b, is a known tumour-suppressor targeting TRAF6 in gliomas [20]. In fact, this miRNA has been reported to be a tumour-suppressor molecule, or conversely, an oncomiR, in many various cancer types [21]. In bladder cancer, it is usually upregulated, and this event is correlated with the inhibitory effect on the invasion of bladder cancer that resulted from the reduction of the matrix metalloproteinase MMP2 expression. It has also been proven that miR-146b knock-down attenuated ETS2 expression in cell lines and in mice, with ETS2 being the significant transcription factor for the expression of MMP2 [21].

Its family 'cousin', miR-146a, is known to be involved in bladder cancer relapse, affecting the function of bladder cancer stem cells both directly and indirectly [22]. It was also shown that miR-146a is important for the maintenance of breast cancer stem cells during the epithelial-mesenchymal transition (EMT) by suppressing the expression of the Notch signalling inhibitor NUMB [23]. It has already been proposed that miR-146a-5p levels measured in the urine samples of patients might be used as a prognostic marker for bladder cancer [22,24]. Interestingly, miR-146a-our fourth-best hit-is known to mediate the suppression of inflammatory response in adipocytes [25], which suggests that it might have a similar effect in cases of cancer disease. The expression of the third-best hit, miR-142-3p, was reported to be linked with reduced regulatory T-cell function in granulomatosis [26]. It also suppresses cell proliferation and cell migration in bladder cancer [27]. These and other miRNAs found to be the most correlated with the expression of checkpoint genes are described in Table 1.

Table 1. The most positively correlated miRNAs and their known functions in human cancers, including bladder cancer, if such a function was reported.

miRNA

hsa-miR-21
Function References

Impact on survival and prognosis in patients with pancreatic cancer; exosomal miR-21 promotes proliferation, but also invasion and therapy resistance of colon adenocarcinoma cells via its target PDCD4; nothing is known about its role in bladder cancer; a lack of miR-21 expression in tumor-associated macrophages (TAMs) promotes antitumoral immune response. 
Table 1. Cont.

\begin{tabular}{|c|c|c|}
\hline miRNA & Function & References \\
\hline hsa-miR-29a & $\begin{array}{l}\text { Downregulated in bladder cancer; shows inhibition of } \\
\text { proliferation in bladder cancer cell lines via PI3K-AKT pathway; } \\
\text { acts as a tumour suppressor in many cancer types; increased } \\
\text { urine levels correlated with shorter event-free survival in most } \\
\text { cancer types; high expression of miR-29a was associated with a } \\
\text { prolonged disease-free survival. }\end{array}$ & [31-35] \\
\hline hsa-miR-100 & $\begin{array}{l}\text { Suggested role in the invasion and metastasis of hepatocellular } \\
\text { carcinoma; involved in the PI3K/AKT and mTOR pathways in } \\
\text { renal carcinoma; interestingly, a variant in the miR-100 gene is a } \\
\text { protective factor of childhood acute lymphoblastic leukaemia. }\end{array}$ & [36-38] \\
\hline hsa-miR-125b & $\begin{array}{l}\text { Suppresses cell proliferation and metastasis by targeting the } \\
\text { HAX-1 gene in esophageal squamous cell carcinoma; regulates } \\
\text { IL-1 } \beta \text {-induced inflammatory genes through targeting } \\
\text { TRAF6-mediated MAPKs and NF- } \mathrm{B} \text { B signaling in human } \\
\text { osteoarthritic chondrocytes; acts as an oncogene in glioblastoma } \\
\text { cells and inhibits cell apoptosis through p53 and } \\
\text { p38MAPK-independent pathways; has a role in conferring the } \\
\text { metastatic phenotype among pancreatic cancer cells; unknown } \\
\text { function in bladder cancer. }\end{array}$ & $\begin{array}{c}\text { [NO_PRINTED_FORM][39- } \\
42]\end{array}$ \\
\hline hsa-miR-142 & $\begin{array}{l}\text { Linked to the reduced regulatory T-cell function in } \\
\text { granulomatosis; suppresses cell proliferation and cell migration } \\
\text { in bladder cancer. }\end{array}$ & {$[25,26]$} \\
\hline hsa-miR-146a & $\begin{array}{l}\text { Mediates the suppression of inflammatory response in } \\
\text { adipocytes; involved in bladder cancer relapse; important for } \\
\text { the maintenance of breast cancer stem cells during EMT; } \\
\text { suggested that the urine levels might be possibly used as a } \\
\text { prognostic marker for bladder cancer; in bladder cancer, it is } \\
\text { usually upregulated, and this event is correlated with the } \\
\text { inhibitory effect on the invasion of cancer cells resulting from } \\
\text { the reduction of MMP2 expression. }\end{array}$ & [20-25] \\
\hline
\end{tabular}

Acts as a tumour promoter: promotes cell proliferation,

migration and invasion of cancer cells through targeting PDCD4 (programmed cell death 4 protein); modulates cisplatin chemosensitivity and invasiveness of muscle-invasive bladder

hsa-miR-150 cancer cells via targeting PDCD4; is suggested as a urinary biomarker for bladder cancer progression; its agonist promotes fibrosis in cultured kidney cells, while its antagonists decrease pro-inflammatory cytokines and pro-fibrotic proteins and increase anti-fibrotic protein SOCS1.

Tumour-promoting and highly oncogenic microRNA that targets ELK3 transcription factor functioning in the hypoxia response; upregulated in breast cancer and linked to PARP-1

hsa-miR-155 inhibitors response; overexpressed in bladder cancer, promoting tumour growth by repressing DMTF1.

Functions as a tumour suppressor in oral squamous cell carcinoma, targeting the IKK $\beta / N F-\kappa B$ signalling pathway;

inhibits malignant progression of lung cancer through mediating RGS17; serum levels were suggested as a potential

hsa-miR-199a diagnostic biomarker for detection of colorectal cancer; recently discovered to inhibit angiogenesis by targeting the VEGF/PI3K/AKT signalling pathway in an in vitro model of diabetic retinopathy; can attenuate aerobic glycolysis and cell proliferation in glioblastoma, but the role in bladder cancer remains unrevealed. 
Table 1. Cont.

\begin{tabular}{|c|c|c|}
\hline miRNA & Function & References \\
\hline hsa-miR-199b & $\begin{array}{l}\text { Downregulated in breast cancer patients; is often associated } \\
\text { with malignant clinical characteristics; exerts tumour } \\
\text { suppressive functions in hepatocellular carcinoma by targeting } \\
\text { JAG1 directly; suppression of miR-199b expressions improves } \\
\text { apoptosis and reduces the cell viability in cervical cancer. }\end{array}$ & [53-56] \\
\hline hsa-miR-221 & $\begin{array}{c}\text { High expression is a poor predictor for glioma; affects } \\
\text { proliferation and apoptosis of gastric cancer cells (through } \\
\text { targeting SOCS3); promotes cisplatin resistance in osteosarcoma } \\
\text { cells by targeting PPP2R2A; the function in bladder cancer is } \\
\text { unknown. }\end{array}$ & [57-59] \\
\hline hsa-miR-223 & $\begin{array}{l}\text { Tumour-suppressive, but also oncogenic miR in various cancers; } \\
\text { targets WDR62 directly in bladder cancer-the knockdown of } \\
\text { WDR62 in mice significantly inhibited tumour aggressiveness } \\
\text { and induced the apoptosis of bladder cancer cells; it may also } \\
\text { inhibit migration and invasion of bladder cancer cells. }\end{array}$ & [60-64] \\
\hline hsa-miR-511 & $\begin{array}{l}\text { circZFR promotes cell proliferation and migration by regulating } \\
\text { the miR-511/AKT1 pathway in hepatocellular carcinoma; } \\
\text { promotes proliferation of human hepatoma cells; functions as a } \\
\text { tumour suppressor and a prognostic marker in colorectal } \\
\text { cancer; contributes to intestinal inflammation; significantly } \\
\text { altered expression and its target } A K T 3 \text { have negative prognostic } \\
\text { value in prostate cancer, but its function in bladder cancer } \\
\text { remains unknown. }\end{array}$ & [65-69] \\
\hline hsa-miR-4772 & $\begin{array}{l}\text { Significance in bladder cancer and immunological surveillance } \\
\text { remains unclear, but a high level in serum exosomes derived } \\
\text { from stage II and stage III colon cancer patients was negatively } \\
\text { associated with the risk of recurrence and the risk of death. }\end{array}$ & {$[70,71]$} \\
\hline hsa-miR-5586 & $\begin{array}{l}\text { Downregulated in pancreatic and bladder cancers; high levels } \\
\text { linked to good outcomes in diffuse large B-cell lymphoma } \\
\text { (DLBCL); significance in bladder cancer and immunological } \\
\text { surveillance remains unknown. }\end{array}$ & {$[72,73]$} \\
\hline hsa-miR-7702 & $\begin{array}{l}\text { Potentially important in colorectal cancer (CRC) progression, } \\
\text { but significance in bladder cancer remains unclear. }\end{array}$ & {$[74,75]$} \\
\hline
\end{tabular}

Correlation with the expression of several other miRNAs have been noted, but with surprisingly low statistical significance, given the information from the existing papers, for example, high miR-34a expression sensitised MIBC to cisplatin, also inhibiting tumorigenicity and cancer cells proliferation [76]. Connection with epigenetic changes was also observed and reported in the literature: cisplatin-based therapy induces demethylation of miR-34a promoter region, and thus, increases its expression [76]. Despite the significance of miR-34a in bladder cancer and suggested role in checkpoint immune mechanisms, it seems unrelated to the expression of checkpoint genes per se.

\subsection{The Most Anti-Correlated miRNAs}

Our top hit in anticorrelated miRs, mir-200a, is known to often play a role in cancer. However, it is reported to regulate the EMT rather than immune response. It is also predictive for prognosis in colorectal cancer patients. Specifically, in bladder cancer, it was reported to be correlated with early-stage and T1 bladder tumour progression [77] and bladder cancer invasion [78]. Overexpressed miR-200a is known to promote bladder cancer invasion through the direct regulation of the axis Dicer/miR-16/JNK2/MMP-2E [78]. Moreover, miR-200a is very important in ovarian carcinoma: it promotes cell invasion and migration by targeting PTEN. The only reports of mir-200a involvement in the immune response to date come from small airway epithelial cells lung cancer [79]. 
Although the role of hsa-miR-200b has not been clear in bladder cancer, it seems particularly significant in renal cancer: it is often downregulated and may suppress metastasis by targeting LAMA4 in renal cell carcinoma [80]. The significantly aberrant expression has also been reported in HER-2 negative breast cancer [81], as well as cardiological pathologies and angiogenesis aberrations $[82,83]$. In breast cancer, it has also been reported that miR-200b may affect breast cancer cells' response to tamoxifen, involving MYB [84]. Moreover, it has been suggested as a prognostic marker in clear cell renal carcinoma [85]. Finally, epigenetic silencing of miR-200b was connected with cisplatin resistance in bladder cancer [86].

miR-200c seems to be particularly important in breast cancer pathogenesis and response to treatment; for example, several authors indicated its role in cancer cell sensitivity to therapy, including trastuzumab use in HER2 positive breast cancer $[87,88]$. Interestingly, miR-200c might act protectively against colorectal cancer through the BMI1 gene complex [89]. Furthermore, it suppresses tumour metastasis by inhibiting EMT in oral squamous carcinoma [90]. Although its role in bladder cancer remains unknown, the level of miR-200c in bladder cancer patients' urine is significantly different from the level in healthy people; thus, it has been suggested as a potential biomarker [32,91].

In our research, miR-200 family seems to be important in the regulation of several checkpoint genes, especially CD48, CD70, CD80, CD86 and PD-L2, as well as transcription factor $\mathrm{BACH} 2$, which is known to be involved in transcription regulation of these genes. This finding suggests that it might be a strong candidate for future investigations, especially those aiming at biomarker discovery and new drug targets.

These and other significant miRs revealed in this study are described in Table 2.

Table 2. The most negatively correlated miRNAs and their known functions in human cancers, including bladder cancer, if such a function is reported.

\begin{tabular}{|c|c|c|}
\hline miRNA & Function & References \\
\hline hsa-miR-30d & $\begin{array}{l}\text { Involved in suppressing endoplasmic reticulum and chaperone and } \\
\text { signalling regulators in several human cancers; suggested as a } \\
\text { tumour supressor in lung cancer initiation and progression. }\end{array}$ & [92-96] \\
\hline hsa-miR-93 & $\begin{array}{l}\text { Probably associated with the prognosis of bladder cancer; known to } \\
\text { promote bladder cancer cells proliferation and invasion via } \\
\text { targeting PEDF gene; involved in sensitivity of bladder cancer to } \\
\text { chemotherapy; promotes hepatocellular carcinoma progression, } \\
\text { possibly via miRNA-93-5p/MAPK/c-Jun positive feddback loop. }\end{array}$ & [97-102] \\
\hline hsa-miR-96 & $\begin{array}{l}\text { Oncogenic miR; potential urinary biomarker in bladder cancer; } \\
\text { involved in EMT and migration and invasion of bladder cancer } \\
\text { cells via targeting CDKN1A; impacts the response to chemotherapy. }\end{array}$ & [103-108] \\
\hline hsa-miR-98 & $\begin{array}{l}\text { Important in the development and progression of bladder cancer } \\
\text { due to its involvement in the WNT/ } \beta \text {-catenin pathway; promotes } \\
\text { drug resistance via targeting the LASS2 gene; axis miR-98/IGF1 } \\
\text { contributes to breast cancer progression. }\end{array}$ & [109-113] \\
\hline hsa-miR-141 & $\begin{array}{l}\text { Might be important in the wound-healing process; promotes } \\
\text { bladder cancer progression, and thus, has prognostic value; in } \\
\text { oesophageal cancer, promotes cell proliferation, migration and } \\
\text { invasion; moreover, in ameloblastoma, it has been shown to supress } \\
\text { cell migration via upregulation of the NCAM1 molecule. }\end{array}$ & [114-117] \\
\hline hsa-miR-151a & $\begin{array}{c}\text { Studied in atopic dermatitis, pain transmission and NOTCH2 } \\
\text { signalling pathway; targeting CHL1 inhibits proliferation and } \\
\text { invasion of colon cancer cells; in nasopharyngeal carcinoma, the } \\
\text { inhibition of p53 by miR-151a induced cell proliferation, migration } \\
\text { and possibly also invasion. }\end{array}$ & [118-121] \\
\hline hsa-miR-182 & $\begin{array}{c}\text { Potentially important in the bladder cancer development, } \\
\text { proliferation and migration; inhibits inflammation, proliferation } \\
\text { and migration of endometrial stromal cells through NFkB pathway } \\
\text { deactivation. }\end{array}$ & [122-125] \\
\hline
\end{tabular}


Table 2. Cont.

\begin{tabular}{|c|c|c|}
\hline miRNA & Function & References \\
\hline hsa-miR-183 & $\begin{array}{l}\text { Involved in the cell adhesion modulation and progression of } \\
\text { laryngeal cancer; reports in bladder cancer indicated its crucial role } \\
\text { in maintaining the canonical WNT signalling pathway, regulating } \\
\text { growth and apoptosis; it has also been reported that cisplatin and } \\
\text { paclitaxel significantly alter the expression of miR-183; potentially } \\
\text { involved in hepatocellular carcinoma cells proliferation by } \\
\text { LNC-HC gene inhibition. }\end{array}$ & [108,126-129] \\
\hline hsa-miR-187 & $\begin{array}{l}\text { Oncogene miR known to be involved in proliferation, migration, } \\
\text { invasion and recurrence bladder cancer; regulates the } \\
\text { WNT/ } \beta \text {-catenin pathway. }\end{array}$ & {$[130,131]$} \\
\hline hsa-miR-191 & $\begin{array}{l}\text { Linked to the antiviral response and intracellular mechanisms of } \\
\text { viral replication, e.g., may inhibit the replication of human } \\
\text { immunodeficiency virus in human cells; circulating miR-191 has } \\
\text { been proposed as a biomarker of breast cancer, as well as squamous } \\
\text { cell carcinoma; it has been suggested to regulate endometrial cancer } \\
\text { cell growth via TET1-mediated epigenetic modulation of APC gene. }\end{array}$ & [132-135] \\
\hline hsa-miR-200a & $\begin{array}{l}\text { Regulation of EMT; probably predictive for a patient's prognosis in } \\
\text { colorectal cancer; reported to be correlated with early-stage and T1 } \\
\text { bladder tumour progression and bladder cancer invasion; when } \\
\text { overexpressed, it promotes bladder cancer invasion. }\end{array}$ & {$[77,78]$} \\
\hline
\end{tabular}

Significant in renal cancer: it is often downregulated and may suppress metastasis by targeting LAMA4 in renal cell carcinoma; aberrant expression has been reported in HER-2 negative breast cancer as well as cardiological pathologies and angiogenesis aberrations; may affect breast cancer cells' response to tamoxifen, involving MYB; it has been suggested as a prognostic marker in clear cell renal carcinoma; epigenetic silencing of miR-200b is connected with cisplatin resistance in bladder cancer.

Important in breast cancer pathogenesis and response to treatment, including trastuzumab use in HER2 positive breast cancer; might

act protectively against colorectal cancer through BMI1 gene hsa-miR-200c complex; it suppresses tumour metastasis by inhibiting EMT in oral squamous carcinoma; the role in bladder cancer remains unknown - the level of miR-200c in bladder cancer patients' urine is significantly different from the level in healthy people, and thus, it has been suggested as a potential biomarker.

hsa-miR-219a

hsa-miR-301b

hsa-miR-423
Inhibits colon cancer progression; enhances the radiosensitivity of lung cancer cells.
$[139,140]$

Accelerates the growth of gastric cancer; promotes the mobility, proliferation and EMT in bladder cancer by targeting EGR1; plasma levels of miR-301b might be a potential biomarker of early stage non-small-cell lung cancer.

It has been proposed as a biomarker, indicating early stages of bladder cancer, especially from blood serum and urine; suppression of miR-423 in breast cancer cells inhibited cell proliferation and invasion.

Known to be involved in the pathogenesis of many cancer types, including bladder; significant role in EMT in bladder cancer; expression levels have been correlated with patient outcomes; it seems to promote proliferation of bladder cancer cells via the 
Table 2. Cont.

\begin{tabular}{|c|c|c|}
\hline miRNA & Function & References \\
\hline hsa-miR-744 & $\begin{array}{c}\text { Although its function in bladder cancer has to be revealed, it seems } \\
\text { important in colorectal cancer, ovarian cancer and heart diseases, } \\
\text { targeting the ARF1 gene; interestingly, it has been reported to be } \\
\text { involved in regulation of the MHC class I gene expression; } \\
\text { contributes to inflammation among patients with Sjorgen } \\
\text { Syndrome; promotes proliferation of osteosarcoma cells by } \\
\text { targeting PTEN. }\end{array}$ & [153-157] \\
\hline hsa-miR-940 & $\begin{array}{c}\text { Known to impact the aggressiveness of bladder cancer cells via } \\
\text { activating the WNT / } \beta \text {-catenin pathway; suggested as a biomarker } \\
\text { of gastric cancer; involved in the hepatocellular cancer and prostate } \\
\text { cancer development. }\end{array}$ & [158-161] \\
\hline hsa-miR-1287 & $\begin{array}{l}\text { Probably regulates the MEK/ERK pathway; the role in immune } \\
\text { surveillance remains unknown. }\end{array}$ & {$[162,163]$} \\
\hline hsa-miR-1306 & $\begin{array}{l}\text { Connected with the SIRT gene family expression; important in } \\
\text { gastric cancer; its role in immune surveillance is to be revealed. }\end{array}$ & [164-166] \\
\hline hsa-miR-1307 & $\begin{array}{l}\text { Upregulation contributes to the progression of gastric cancer; } \\
\text { indicates the metastatic potential of hepatocellular carcinoma; by } \\
\text { targeting TRAF3 gene, it also regulates the MAPK/NFkB pathway } \\
\text { in lung adenocarcinoma, promoting cancer cells' proliferation. }\end{array}$ & [167-169] \\
\hline hsa-miR-3193 & $\begin{array}{l}\text { Very little is known about this miR; however, its role has been } \\
\text { reported in melanoma pathogenesis. }\end{array}$ & [170] \\
\hline hsa-miR-3200 & Acting in gastric cancer tumorigenesis and progression. & [171-173] \\
\hline hsa-miR-4756 & $\begin{array}{l}\text { Seems to be particularly important in triple-negative breast cancer } \\
\text { pathogenesis; also reported in the EMT process. }\end{array}$ & {$[174,175]$} \\
\hline hsa-miR-4778 & $\begin{array}{l}\text { Might be involved in radioresistance development in cervical } \\
\text { cancer. }\end{array}$ & [176] \\
\hline hsa-miR-7706 & $\begin{array}{c}\text { Little is known about this miR and its function in cancer } \\
\text { pathogenesis; in hepatocellular carcinoma, it seems to have a } \\
\text { prognostic value. }\end{array}$ & [177] \\
\hline
\end{tabular}

\subsection{Other miRNAs Important in Bladder Cancer}

There are several miRNAs described extensively in the bladder cancer literature, but surprisingly, they are not significantly correlated with any of the analysed genes. For example, miR-497 was significantly downregulated in bladder transitional cell carcinoma cells and tissues [8]. This led to the upregulation of the transcription factor E2F3 and suppression of cell proliferation and invasion [8]. On the other hand, the transcription factor E2F has been shown to regulate the expression of miR-15b, a member of the same miR family as miR-497 [137]. Similarly, miR-106a had an inhibitory effect on the proliferation of BC cells through the modulation of MAPK signalling [8].

Several authors have already emphasised the importance of immune cells infiltrations in the tumour as a key component of the patient's response to PD-1/PD-L1 checkpoint inhibition. Additionally, the presence of specific cells and/or components in the cancer microenvironment can be crucial, for example, in myeloid cells. This phenomenon was observed not only in melanoma or bladder cancer, but also in other not-so-well-investigated cancer types in terms of immunotherapy, such as pancreatic cancer [178]. MicroRNAs have been shown to be important in the patient's response to therapy. For instance, in chemoresistant ovarian cancer, miR-424 has been proved to regulate the PD-1/PD-L1 and CTLA-4/CD80 pathways [179]. The expression of miR-424 is inversely correlated with the expression of PD-1, PD-L1, CTLA-4 and CD80 genes, and it has been shown that miR-424 inhibited the expression of those genes through direct binding to the 3'UTRs [99]. Moreover, 
the progression-free survival (PFS) of ovarian cancer patients has been positively correlated with high levels of this miR [179].

\subsection{Limitations to the Research Presented}

As in any research, there are several limitations to our work which need to be mentioned. First, our results are based on the retrospective analysis of a single dataset of 402 cancer samples. The correlations should, therefore, be verified using other data cohorts. Secondly, our analysis is based on the expression data. The RNA-seq data do not measure the final concentration of protein in the cytoplasm and at the cell surface. With a comprehensive proteomics dataset, a more in-depth analysis of actual protein levels and protein-protein interactions at the cancer cell membrane could be performed. This is especially important for the surface proteins of the immunological synapse.

\section{Materials and Methods}

\subsection{Data Acquisition and Pre-Processing}

We acquired miRNA expression, mRNA expression and clinical metadata for cancer cohorts from The Cancer Genome Atlas (TCGA) database using the "TCGAbiolinks" package in R (see Supplementary Materials Section). For correlation analyses, we used the results of "HTSeq - FPKM" workflows for mRNA and read counts for miRNA. We discarded duplicates of the same patient and selected only for experiments where the matching sample was profiled for gene expression and miRNA expression. Of note, healthy tissue samples marked as "controls" were derived from the same patients from which the tumour samples were derived.

\subsection{Correlation Analyses}

Based on the literature, 21 genes potentially expressed at cancer/APC side of the immunological synapse were selected for further analyses. We selected mRNAs of interest and created an $\mathrm{n} \times \mathrm{m}$ numeric matrix of expression measures representing reads per million per kilobase of transcript (RPKM) for RNA-seq, where $n$ is the number of individual samples and $m$ is the number of pre-selected mRNAs. In a similar manner, we created a matrix presenting microRNA expression values-an $\mathrm{n} \times \mathrm{k}$ numeric matrix of expression values, where $n$ is the number of individual samples and $\mathrm{k}$ is the number of miRNAs.

We then generated a nonparametric correlation matrix between miRNA and mRNA expression values using Spearman's rank-order correlation coefficient implemented in R. The statistical significance of each correlation is determined using a correlation test: a t-test is applied to the individual correlations using the following formula: $t=r^{*} \operatorname{sqrt}(n-2) / \operatorname{sqrt}(1-$ $\left.\mathrm{r}^{\wedge} 2\right)$. This method is implemented in the "psych" package. The $p$-values are then corrected to q-values using the false detection rate (FDR) method [179]. The resulting correlations and associated q-values are visualised for further inspection using a custom correlation heatmap drown in "GGplot2" package. Because of the large number of miRNAs, we also provide interactive heatmaps drown using "d3heatmap" package. All interactive and full static heatmaps are available in the Supplementary Materials Section. For figures shown in the manuscript, in the interest of clear visualisation, we have filtered out miRNAs with only non-significant or low correlations to 21 re-selected mRNAs.

\subsection{Graphical Model Estimation for Correlation Networks}

Correlation graphs represent the correlation matrix with nodes that indicate genes of interest and edges that represent correlation values. Green edges indicate positive correlations and red edges negative ones. The width of the edges and their colour saturation corresponds to the absolute value of correlations and scale relative to the strongest weight in the graph. The graphs are organised as "spring" layout, which uses the FruchtermanReingold algorithm [11] to obtain a force-directed layout. In this solution, each node (connected and unconnected) repulses the other, while connected nodes attract each other. After a number of iterations (500), a final logout is reached-the distance between the 
nodes corresponds well to the correlation between the nodes, where correlated nodes are close to each other, while anticorrelated (negative correlation) nodes are moved to distant parts of the graph.

\section{Conclusions}

Our results clearly indicate several miRNAs that might be important in post-transcriptional checkpoint genes regulation on tumour side of the immunological synapse. Moreover, some microRNAs might indirectly participate in transcriptional regulation of checkpoint genes in bladder cancer. Further experimental research is required to confirm and quantify these interactions. MicroRNAs acting as moderators of immune response at the cancer side of the synapse are promising drug candidates and biomarkers. They can be used directly as novel biologics to modulate the synapse, aiming to increase tumour immunogenicity, and thus, as the response to the immune checkpoint inhibitor therapy in bladder cancer. Despite our better understanding of immune response regulation and new checkpoint inhibitor therapeutics being introduced to the market, cisplatin-based chemotherapy remains the major therapeutic agent used to treat bladder cancer worldwide [5]. Only about half of patients respond to this treatment, and eventually, all patients develop a chemotherapy resistance $[5,180]$. Therefore, we see a crucial need for finding new, highly individualised therapeutic strategies together with molecular biomarker-based companion diagnostics. MicroRNAs play a crucial role in many, if not most, of the processes leading to the development, growth, invasiveness and progression of the tumour. Given their favourable molecular characteristics and ease of detection, they are promising biomarker and therapeutic target candidates. We postulate that further research into the function of microRNA in cancer will yield predictive and prognostic biomarkers to be used in rapid, inexpensive and accurate diagnostics [14].

Supplementary Materials: Figure S1: Heatmap showing all corelations between selected gens and miRNAs as PDF; Figure S2: Interactive heatmap showing all corelations between selected gens and miRNAs—online resource at https:/ / przemol.github.io/blca/ [181,182].

Author Contributions: Conceptualisation, P.A.S., R.L., Y.S., D.A. and P.D.; methodology, P.A.S. and P.D.; software, P.A.S.; writing-original draft preparation, P.D., T.D. and M.S.; writing-review and editing, M.S., P.D. and T.D.; visualisation, P.D., P.A.S. and Y.S.; supervision, P.D., Y.S., D.A. and R.L. All authors have read and agreed to the published version of the manuscript.

Funding: This research received no external funding.

Institutional Review Board Statement: Not applicable.

Informed Consent Statement: Not applicable.

Data Availability Statement: Not applicable.

Conflicts of Interest: The authors declare no conflict of interest.

\section{References}

1. MedlinePlus Genetics Home Reference-What Is Precision Medicine? Available online: https: / / medlineplus.gov / about (accessed on 8 January 2021).

2. Smith, R. Stratified, Personalised, or Precision Medicine. Available online: https://blogs.bmj.com/bmj/2012/10/15/richardsmith-stratified-personalised-or-precision-medicine (accessed on 8 January 2021).

3. O'Shaughnessy, K. Lecture on Stratified Medicine; Cambridge University: Cambridge, UK, 2017.

4. Nordentoft, I.; Dyrskjøt, L.; Bødker, J.S.; Wild, P.J.; Hartmann, A.; Bertz, S.; Lehmann, J.; Ørntoft, T.F.; Birkenkamp-Demtroder, K. Increased Expression of Transcription Factor TFAP2 Correlates with Chemosensitivity in Advanced Bladder Cancer. BMC Cancer 2011, 11. [CrossRef] [PubMed]

5. Faltas, B.M.; Prandi, D.; Tagawa, S.T.; Molina, A.M.; Nanus, D.M.; Sternberg, C.; Rosenberg, J.; Mosquera, J.M.; Robinson, B.; Elemento, O.; et al. Clonal Evolution of Chemotherapy-Resistant Urothelial Carcinoma. Nat. Genet. 2016, 48, 1490-1499. [CrossRef] [PubMed]

6. Hornstein, E.; Shomron, N. Canalization of Development by MicroRNAs. Nat. Genet. 2006, 38, S20-S24. [CrossRef] 
7. Calin, G.A.; Cimmino, A.; Fabbri, M.; Ferracin, M.; Wojcik, S.E.; Shimizu, M.; Taccioli, C.; Zanesi, N.; Garzon, R.; Aqeilan, R.I.; et al. MiR-15a and MiR-16-1 Cluster Functions in Human Leukemia. Proc. Natl. Acad. Sci. USA 2008, 105, 5166-5171. [CrossRef]

8. Zhao, X.; Ji, Z.; Xie, Y.; Liu, G.; Li, H. MicroRNA-154 as a Prognostic Factor in Bladder Cancer Inhibits Cellular Malignancy by Targeting RSF1 and RUNX2. Oncol. Rep. 2017, 38, 2727-2734. [CrossRef]

9. Aqeilan, R.I.; Calin, G.A.; Croce, C.M. MiR-15a and MiR-16-1 in Cancer: Discovery, Function and Future Perspectives. Cell Death Differ. 2009, 17, 215-220. [CrossRef]

10. Pecorino, L. Molecular Biology of Cancer, 4th ed.; Oxford University Press: Oxford, UK, 2016.

11. Esquela-Kerscher, A.; Slack, F.J. Oncomirs MicroRNAs with a Role in Cancer. Nat. Rev. Cancer 2006, 6, 259-269. [CrossRef]

12. Cimmino, A.; Calin, G.A.; Fabbri, M.; Iorio, M.V.; Ferracin, M.; Shimizu, M.; Wojcik, S.E.; Aqeilan, R.I.; Zupo, S.; Dono, M.; et al. MiR-15 and MiR-16 Induce Apoptosis by Targeting BCL2. Proc. Natl. Acad. Sci. USA 2005, 102, 13944-13949. [CrossRef]

13. Messing, E.M. Checkpoint Inhibitors for Advanced Bladder Cancer. Bladder Cancer 2016, 2, 473-474. [CrossRef]

14. Knowles, M.A.; Hurst, C.D. Molecular Biology of Bladder Cancer: New Insights into Pathogenesis and Clinical Diversity. Nat. Rev. Cancer 2014, 15, 25-41. [CrossRef]

15. Shien, K.; Papadimitrakopoulou, V.A.; Wistuba, I.I. Predictive Biomarkers of Response to PD-1/PD-L1 Immune Checkpoint Inhibitors in Nonsmall Cell Lung Cancer. Lung Cancer 2016, 99, 79-87. [CrossRef] [PubMed]

16. Dobosz, P.; Stempor, P.A.; Roszik, J.; Herman, A.; Layani, A.; Berger, R.; Avni, D.; Sidi, Y.; Leibowitz-Amit, R. Checkpoint Genes at the Cancer Side of the Immunological Synapse in Bladder Cancer. Transl. Oncol. 2020, 13. [CrossRef] [PubMed]

17. Robertson, E.D.; Wasylyk, C.; Ye, T.; Jung, A.C.; Wasylyk, B. The Oncogenic MicroRNA Hsa-MiR-155-5p Targets the Transcription Factor ELK3 and Links It to the Hypoxia Response. PLoS ONE 2014, 9. [CrossRef]

18. Pasculli, B.; Barbano, R.; Fontana, A.; Biagini, T.; di Viesti, M.P.; Rendina, M.; Valori, V.M.; Morritti, M.; Bravaccini, S.; Ravaioli, S.; et al. Hsa-MiR-155-5p Up-Regulation in Breast Cancer and Its Relevance for Treatment with Poly[ADP-Ribose] Polymerase 1 (PARP-1) Inhibitors. Front. Oncol. 2020, 10. [CrossRef]

19. Peng, Y.; Dong, W.; Lin, T.; Zhong, G.; Liao, B.; Wang, B.; Gu, P.; Huang, L.; Xie, Y.; Lu, F.; et al. MicroRNA-155 Promotes Bladder Cancer Growth by Repressing the Tumor Suppressor DMTF1. Oncotarget 2015, 6. [CrossRef] [PubMed]

20. Liu, J.; Xu, J.; Li, H.; Sun, C.; Yu, L.; Li, Y.; Shi, C.; Zhou, X.; Bian, X.; Ping, Y.; et al. MiR-146b-5p Functions as a Tumor Suppressor by Targeting TRAF6 and Predicts the Prognosis of Human Gliomas. Oncotarget 2015, 6. [CrossRef]

21. Zhu, J.; Xu, C.; Ruan, L.; Wu, J.; Li, Y.; Zhang, X. MicroRNA-146b Overexpression Promotes Human Bladder Cancer Invasion via Enhancing ETS2-Mediated Mmp2 MRNA Transcription. Mol. Nucleic Acids 2019, 16. [CrossRef]

22. Wang, T.; Yang, Y.; Wang, Z.; Zhang, X.; Li, D.; Wei, J. A SNP of MiR-146a Is Involved in Bladder Cancer Relapse by Affecting the Function of Bladder Cancer Stem Cells via the MiR-146a Signallings. J. Cell. Mol. Med. 2020, 24. [CrossRef] [PubMed]

23. Wang, X.; Lu, H.; Li, T.; Yu, L.; Liu, G.; Peng, X.; Zhao, J. Krüppel-like Factor 8 Promotes Tumorigenic Mammary Stem Cell Induction by Targeting MiR-146a. Am. J. Cancer Res. 2013, 3, 356-373. [PubMed]

24. Sasaki, H.; Yoshiike, M.; Nozawa, S.; Usuba, W.; Katsuoka, Y.; Aida, K.; Kitajima, K.; Kudo, H.; Hoshikawa, M.; Yoshioka, Y.; et al. Expression Level of Urinary MicroRNA-146a-5p Is Increased in Patients With Bladder Cancer and Decreased in Those After Transurethral Resection. Clin. Genitourin. Cancer 2016, 14. [CrossRef] [PubMed]

25. Roos, J.; Enlund, E.; Funcke, J.-B.; Tews, D.; Holzmann, K.; Debatin, K.-M.; Wabitsch, M.; Fischer-Posovszky, P. MiR-146a-Mediated Suppression of the Inflammatory Response in Human Adipocytes. Sci. Rep. 2016, 6. [CrossRef]

26. Dekkema, G.J.; Bijma, T.; Jellema, P.G.; van den Berg, A.; Kroesen, B.-J.; Stegeman, C.A.; Heeringa, P.; Abdulahad, W.H.; Sanders, J.-S. Increased MiR-142-3p Expression Might Explain Reduced Regulatory T Cell Function in Granulomatosis with Polyangiitis. Front. Immunol. 2019, 10. [CrossRef]

27. Li, W.Q.; Zhao, W.C.; Xin, J.; Niu, T.L.; Chao, Y.F.; Zhou, P.; Zheng, M.H.; Xu, B. MicroRNA-142-3p Suppresses Cell Proliferation and Migration in Bladder Cancer via Rac1. J. Biol. Regul. Homeost. Agents 2020, 34. [CrossRef]

28. Zhang, W.; Chen, J.; He, G.; Xu, W.; He, G. Impact of Mirna-21 on Survival Prognosis in Patients with Pancreatic Cancer. Medicine 2020, 99. [CrossRef] [PubMed]

29. Sun, L.-H.; Tian, D.; Yang, Z.-C.; Li, J.-L. Exosomal MiR-21 Promotes Proliferation, Invasion and Therapy Resistance of Colon Adenocarcinoma Cells through Its Target PDCD4. Sci. Rep. 2020, 10. [CrossRef]

30. Sahraei, M.; Chaube, B.; Liu, Y.; Sun, J.; Kaplan, A.; Price, N.L.; Ding, W.; Oyaghire, S.; García-Milian, R.; Mehta, S.; et al. Suppressing MiR-21 Activity in Tumor-Associated Macrophages Promotes an Antitumor Immune Response. J. Clin. Investig. 2019, 129. [CrossRef]

31. Chen, L.; Yuan, L.; Wang, G.; Cao, R.; Peng, J.; Shu, B.; Qian, G.; Wang, X.; Xiao, Y. Identification and Bioinformatics Analysis of MiRNAs Associated with Human Muscle Invasive Bladder Cancer. Mol. Med. Rep. 2017, 16. [CrossRef] [PubMed]

32. Cavallari, I.; Grassi, A.; del Bianco, P.; Aceti, A.; Zaborra, C.; Sharova, E.; Bertazzolo, I.; D'A Agostino, D.M.; Iafrate, M.; Ciminale, V. Prognostic Stratification of Bladder Cancer Patients with a MicroRNA-Based Approach. Cancers 2020, 12, 3133. [CrossRef]

33. Jiang, H.; Zhang, G.; Wu, J.-H.; Jiang, C.-P. Diverse Roles of MiR-29 in Cancer (Review). Oncol. Rep. 2014, 31. [CrossRef] [PubMed]

34. Weissmann-Brenner, A.; Kushnir, M.; Lithwick Yanai, G.; Aharonov, R.; Gibori, H.; Purim, O.; Kundel, Y.; Morgenstern, S.; Halperin, M.; Niv, Y.; et al. Tumor MicroRNA-29a Expression and the Risk of Recurrence in Stage II Colon Cancer. Int. J. Oncol. 2012. [CrossRef]

35. Fan, Y.; Song, X.; Du, H.; Luo, C.; Wang, X.; Yang, X.; Wang, Y.; Wu, X. Down-Regulation of MiR-29c in Human Bladder Cancer and the Inhibition of Proliferation in T24 Cell via PI3K-AKT Pathway. Med. Oncol. 2014, 31. [CrossRef] 
36. Cai, J.P.; Zhou, X.H.; Yu, H.B.; Li, D.Y.; Zhou, B.X. Study on the Clinical Significance of MiR-100 Expression in the Invasion and Metastasis of Hepatocellular Carcinoma. Chin. J. Hepatol. 2020, 28, 930-935.

37. Chen, T.; Shao, S.; Li, W.; Liu, Y.; Cao, Y. The Circular RNA Hsa-Circ-0072309 Plays Anti-Tumour Roles by Sponging MiR-100 through the Deactivation of PI3K/AKT and MTOR Pathways in the Renal Carcinoma Cell Lines. Artif. Cells Nanomed. Biotechnol. 2019, 47. [CrossRef] [PubMed]

38. Xue, Y.; Yang, X.; Hu, S.; Kang, M.; Chen, J.; Fang, Y. A Genetic Variant in MiR-100 Is a Protective Factor of Childhood Acute Lymphoblastic Leukemia. Cancer Med. 2019, 8. [CrossRef]

39. Wu, N.; Lin, X.; Zhao, X.; Zheng, L.; Xiao, L.; Liu, J.; Ge, L.; Cao, S. MiR-125b Acts as an Oncogene in Glioblastoma Cells and Inhibits Cell Apoptosis through P53 and P38MAPK-Independent Pathways. Br. J. Cancer 2013, 109. [CrossRef]

40. Wu, M.; Tan, X.; Liu, P.; Yang, Y.; Huang, Y.; Liu, X.; Meng, X.; Yu, B.; Wu, Y.; Jin, H. Role of Exosomal MicroRNA-125b-5p in Conferring the Metastatic Phenotype among Pancreatic Cancer Cells with Different Potential of Metastasis. Life Sci. 2020, 255. [CrossRef]

41. Yu, Z.; Ni, F.; Chen, Y.; Zhang, J.; Cai, J.; Shi, W. MiR-125b Suppresses Cell Proliferation and Metastasis by Targeting HAX-1 in Esophageal Squamous Cell Carcinoma. Pathol. Res. Pract. 2020, 216. [CrossRef] [PubMed]

42. Rasheed, Z.; Rasheed, N.; Abdulmonem, W.A.; Khan, M.I. MicroRNA-125b-5p Regulates IL-1 $\beta$ Induced Inflammatory Genes via Targeting TRAF6-Mediated MAPKs and NF-KB Signaling in Human Osteoarthritic Chondrocytes. Sci. Rep. 2019, 9. [CrossRef] [PubMed]

43. Zhang, Z.; Wang, J.; Li, J.; Wang, X.; Song, W. MicroRNA-150 Promotes Cell Proliferation, Migration, and Invasion of Cervical Cancer through Targeting PDCD4. Biomed. Pharmacother. 2018, 97. [CrossRef] [PubMed]

44. Lei, Y.; Hu, X.; Li, B.; Peng, M.; Tong, S.; Zu, X.; Wang, Z.; Qi, L.; Chen, M. MiR-150 Modulates Cisplatin Chemosensitivity and Invasiveness of Muscle-Invasive Bladder Cancer Cells via Targeting PDCD4 In Vitro. Med. Sci. Monit. 2014, 20. [CrossRef]

45. Chen, C.-L.; Lin, C.-H.; Li, A.-L.; Huang, C.-C.; Shen, B.-Y.; Chiang, Y.-R.; Fang, P.-L.; Chang, H.-C.; Li, K.-L.; Yang, W.-C.; et al. Plasma MiRNA Profile Is a Biomarker Associated with Urothelial Carcinoma in Chronic Hemodialysis Patients. Am. J. Physiol. Ren. Physiol. 2019, 316. [CrossRef]

46. Lian, J.; Lin, S.-H.; Ye, Y.; Chang, D.W.; Huang, M.; Dinney, C.P.; Wu, X. Serum MicroRNAs as Predictors of Risk for Non-Muscle Invasive Bladder Cancer. Oncotarget 2018, 9. [CrossRef] [PubMed]

47. Luan, J.; Fu, J.; Chen, C.; Jiao, C.; Kong, W.; Zhang, Y.; Chang, Q.; Wang, Y.; Li, D.; Illei, G.G.; et al. LNA-Anti-MiR-150 Ameliorated Kidney Injury of Lupus Nephritis by Inhibiting Renal Fibrosis and Macrophage Infiltration. Arthritis Res. Ther. 2019, 21. [CrossRef] [PubMed]

48. Wei, D.; Shen, B.; Wang, W.; Zhou, Y.; Yang, X.; Lu, G.; Yang, J.; Shao, Y. MicroRNA-199a-5p Functions as a Tumor Suppressor in Oral Squamous Cell Carcinoma via Targeting the IKK $\beta / N F-\kappa B$ Signaling Pathway. Int. J. Mol. Med. 2019. [CrossRef]

49. Su, W.Z.; Ren, L.F. MiRNA-199 Inhibits Malignant Progression of Lung Cancer through Mediating RGS17. Eur. Rev. Med Pharmacol. Sci. 2019, 23, 3390-3400. [CrossRef] [PubMed]

50. Wang, L.; Liu, W.-X.; Huang, X.-G. MicroRNA-199a-3p Inhibits Angiogenesis by Targeting the VEGF/PI3K/AKT Signalling Pathway in an in Vitro Model of Diabetic Retinopathy. Exp. Mol. Pathol. 2020, 116. [CrossRef]

51. Tan, H.Y.; Zheng, Y.B.; Liu, J. Serum MiR-199a as a Potential Diagnostic Biomarker for Detection of Colorectal Cancer. Eur. Rev. Med. Pharmacol. Sci. 2018, 22, 8657-8663. [CrossRef]

52. Zhang, H.; Qin, D.; Jiang, Z.; Zhang, J. SNHG9/MiR-199a-5p/Wnt2 Axis Regulates Cell Growth and Aerobic Glycolysis in Glioblastoma. J. Neuropathol. Exp. Neurol. 2019, 78. [CrossRef] [PubMed]

53. Li, G.L.; Yuan, J.H.; Zhuang, G.D.; Wu, D.Q. MiR-199b Exerts Tumor Suppressive Functions in Hepatocellular Carcinoma by Directly Targeting JAG1. Eur. Rev. Med. Pharmacol. Sci. 2018, 22, 7679-7687. [CrossRef] [PubMed]

54. Fang, C.; Wang, F.-B.; Li, Y.; Zeng, X.-T. Down-Regulation of MiR-199b-5p Is Correlated with Poor Prognosis for Breast Cancer Patients. Biomed. Pharmacother. 2016, 84. [CrossRef] [PubMed]

55. Pan, P.; Weisenberger, D.J.; Zheng, S.; Wolf, M.; Hwang, D.G.; Rose-Nussbaumer, J.R.; Jurkunas, U.V.; Chan, M.F. Aberrant DNA Methylation of MiRNAs in Fuchs Endothelial Corneal Dystrophy. Sci. Rep. 2019, 9. [CrossRef] [PubMed]

56. Xu, L.-J.; Duan, Y.; Wang, P.; Yin, H.-Q. MiR-199b-5p Promotes Tumor Growth and Metastasis in Cervical Cancer by downRegulating KLK10. Biochem. Biophys. Res. Commun. 2018, 503. [CrossRef] [PubMed]

57. Song, Y.; He, M.; Zhang, J.; Xu, J. High Expression of MicroRNA 221 Is a Poor Predictor for Glioma. Medicine 2020, 99. [CrossRef]

58. Zhou, Q.Y.; Peng, P.L.; Xu, Y.H. MiR-221 Affects Proliferation and Apoptosis of Gastric Cancer Cells through Targeting SOCS3. Eur. Rev. Med. Pharmacol. Sci. 2019, 23, 9427-9435. [CrossRef]

59. Yu, W.; Chen, H.; Qu, Y.; Xu, C.; Yang, C.; Liu, Y. MicroRNA-221 Promotes Cisplatin Resistance in Osteosarcoma Cells by Targeting PPP2R2A. Biosci. Rep. 2019, 39. [CrossRef]

60. Sugita, S.; Yoshino, H.; Yonemori, M.; Miyamoto, K.; Matsushita, R.; Sakaguchi, T.; Itesako, T.; Tatarano, S.; Nakagawa, M.; Enokida, H. Tumor-suppressive MicroRNA-223 Targets WDR62 Directly in Bladder Cancer. Int. J. Oncol. 2019. [CrossRef]

61. Bradford, M. A Rapid and Sensitive Method for the Quantitation of Microgram Quantities of Protein Utilizing the Principle of Protein-Dye Binding. Anal. Biochem. 1976, 72. [CrossRef]

62. Schindelman, G.; Fernandes, J.S.; Bastiani, C.A.; Yook, K.; Sternberg, P.W. Worm Phenotype Ontology: Integrating Phenotype Data within and beyond the C. Elegans Community. BMC Bioinform. 2011, 12. [CrossRef] [PubMed] 
63. Guo, J.; Cao, R.; Yu, X.; Xiao, Z.; Chen, Z. MicroRNA-223-3p Inhibits Human Bladder Cancer Cell Migration and Invasion. Tumor Biol. 2017, 39. [CrossRef] [PubMed]

64. Li, S.; Feng, Y.; Huang, Y.; Liu, Y.; Wang, Y.; Liang, Y.; Zeng, H.; Qu, H.; Wei, L. MiR-223-3p Regulates Cell Viability, Migration, Invasion, and Apoptosis of Non-Small Cell Lung Cancer Cells by Targeting RHOB. Open Life Sci. 2020, 15. [CrossRef]

65. Yang, X.; Liu, L.; Zou, H.; Zheng, Y.-W.; Wang, K.-P. CircZFR Promotes Cell Proliferation and Migration by Regulating MiR511/AKT1 Axis in Hepatocellular Carcinoma. Dig. Liver Dis. 2019, 51. [CrossRef] [PubMed]

66. Zhang, S.; Yang, Z.; Cai, X.; Zhao, M.; Sun, M.; Li, J.; Feng, G.; Feng, J.; Ye, L.; Niu, J.; et al. MiR-511 Promotes the Proliferation of Human Hepatoma Cells by Targeting the 3'UTR of B Cell Translocation Gene 1 (BTG1) MRNA. Acta Pharmacol. Sin. 2017, 38. [CrossRef] [PubMed]

67. Wang, C.; Fan, H.Q.; Zhang, Y.W. MiR-511-5p Functions as a Tumor Suppressor and a Predictive of Prognosis in Colorectal Cancer by Directly Targeting GPR116. Eur. Rev. Med. Pharmacol. Sci. 2019, 23, 6119-6130. [CrossRef] [PubMed]

68. Heinsbroek, S.E.M.; Squadrito, M.L.; Schilderink, R.; Hilbers, F.W.; Verseijden, C.; Hofmann, M.; Helmke, A.; Boon, L.; Wildenberg, M.E.; Roelofs, J.J.T.H.; et al. MiR-511-3p, Embedded in the Macrophage Mannose Receptor Gene, Contributes to Intestinal Inflammation. Mucosal Immunol. 2016, 9. [CrossRef]

69. Zhang, F.; Wu, Z. Significantly Altered Expression of MiR-511-3p and Its Target AKT3 Has Negative Prognostic Value in Human Prostate Cancer. Biochimie 2017, 140. [CrossRef]

70. Wang, H.; Peng, R.; Wang, J.; Qin, Z.; Xue, L. Circulating MicroRNAs as Potential Cancer Biomarkers: The Advantage and Disadvantage. Clin. Epigenetics 2018, 10. [CrossRef]

71. Liu, C.; Eng, C.; Shen, J.; Lu, Y.; Takata, Y.; Mehdizadeh, A.; Chang, G.J.; Rodriguez-Bigas, M.A.; Li, Y.; Chang, P.; et al. Serum Exosomal MiR-4772-3p Is a Predictor of Tumor Recurrence in Stage II and III Colon Cancer. Oncotarget 2016, 7. [CrossRef]

72. Bai, X.; Lu, D.; Lin, Y.; Lv, Y.; He, L. A Seven-miRNA Expression-based Prognostic Signature and Its Corresponding Potential Competing Endogenous RNA Network in Early Pancreatic Cancer. Exp. Ther. Med. 2019. [CrossRef]

73. Lim, E.L.; Trinh, D.L.; Scott, D.W.; Chu, A.; Krzywinski, M.; Zhao, Y.; Robertson, A.G.; Mungall, A.J.; Schein, J.; Boyle, M.; et al. Comprehensive MiRNA Sequence Analysis Reveals Survival Differences in Diffuse Large B-Cell Lymphoma Patients. Genome Biol. 2015, 16. [CrossRef] [PubMed]

74. Qian, J.; Zeng, L.; Jiang, X.; Zhang, Z.; Luo, X. Novel Multiple MiRNA-Based Signatures for Predicting Overall Survival and Recurrence-Free Survival of Colorectal Cancer Patients. Med. Sci. Monit. 2019, 25. [CrossRef] [PubMed]

75. Liu, H.; Li, D.; Fang, H.; Ning, J. Species-Specific Function of MicroRNA-7702 in Human Colorectal Cancer Cells via Targeting TADA1. Am. J. Transl. Res. 2018, 10, 2579-2589.

76. Li, H.; Yu, G.; Shi, R.; Lang, B.; Chen, X.; Xia, D.; Xiao, H.; Guo, X.; Guan, W.; Ye, Z.; et al. Correction: Cisplatin-Induced Epigenetic Activation of MiR-34a Sensitizes Bladder Cancer Cells to Chemotherapy. Mol. Cancer 2014, 13, 183. [CrossRef]

77. Wiklund, E.D.; Bramsen, J.B.; Hulf, T.; Dyrskjøt, L.; Ramanathan, R.; Hansen, T.B.; Villadsen, S.B.; Gao, S.; Ostenfeld, M.S.; Borre, M.; et al. Coordinated Epigenetic Repression of the MiR-200 Family and MiR-205 in Invasive Bladder Cancer. Int. J. Cancer 2011, 128. [CrossRef]

78. Yang, R.; Xu, J.; Hua, X.; Tian, Z.; Xie, Q.; Li, J.; Jiang, G.; Cohen, M.; Sun, H.; Huang, C. Overexpressed MiR-200a Promotes Bladder Cancer Invasion through Direct Regulating Dicer/MiR-16/JNK2/MMP-2 Axis. Oncogene 2020, 39. [CrossRef]

79. Pacurari, M.; Addison, J.B.; Bondalapati, N.; Wan, Y.-W.; Luo, D.; Qian, Y.; Castranova, V.; Ivanov, A.V.; Guo, N.L. The MicroRNA200 Family Targets Multiple Non-Small Cell Lung Cancer Prognostic Markers in H1299 Cells and BEAS-2B Cells. Int. J. Oncol. 2013, 43. [CrossRef] [PubMed]

80. Li, Y.; Guan, B.; Liu, J.; Zhang, Z.; He, S.; Zhan, Y.; Su, B.; Han, H.; Zhang, X.; Wang, B.; et al. MicroRNA-200b Is Downregulated and Suppresses Metastasis by Targeting LAMA4 in Renal Cell Carcinoma. EBioMedicine 2019, 44. [CrossRef] [PubMed]

81. Braicu, C.; Raduly, L.; Morar-Bolba, G.; Cojocneanu, R.; Jurj, A.; Pop, L.-A.; Pileczki, V.; Ciocan, C.; Moldovan, A.; Irimie, A.; et al. Aberrant MiRNAs Expressed in HER-2 Negative Breast Cancers Patient. J. Exp. Clin. Cancer Res. 2018, 37. [CrossRef] [PubMed]

82. Maleki, S.; Cottrill, K.A.; Poujade, F.-A.; Bhattachariya, A.; Bergman, O.; Gådin, J.R.; Simon, N.; Lundströmer, K.; Franco-Cereceda, A.; Björck, H.M.; et al. The Mir-200 Family Regulates Key Pathogenic Events in Ascending Aortas of Individuals with Bicuspid Aortic Valves. J. Intern. Med. 2019, 285. [CrossRef]

83. Moh-Moh-Aung, A.; Fujisawa, M.; Ito, S.; Katayama, H.; Ohara, T.; Ota, Y.; Yoshimura, T.; Matsukawa, A. Decreased MiR-200b-3p in Cancer Cells Leads to Angiogenesis in HCC by Enhancing Endothelial ERG Expression. Sci. Rep. 2020, 10. [CrossRef]

84. Gao, Y.; Zhang, W.; Liu, C.; Li, G. MiR-200 Affects Tamoxifen Resistance in Breast Cancer Cells through Regulation of MYB. Sci. Rep. 2019, 9. [CrossRef]

85. Saleeb, R.; Kim, S.S.; Ding, Q.; Scorilas, A.; Lin, S.; Khella, H.W.; Boulos, C.; Ibrahim, G.; Yousef, G.M. The MiR-200 Family as Prognostic Markers in Clear Cell Renal Cell Carcinoma. Urol. Oncol. Semin. Orig. Investig. 2019, 37. [CrossRef]

86. Shindo, T.; Niinuma, T.; Nishiyama, N.; Shinkai, N.; Kitajima, H.; Kai, M.; Maruyama, R.; Tokino, T.; Masumori, N.; Suzuki, H. Epigenetic Silencing of MiR-200b Is Associated with Cisplatin Resistance in Bladder Cancer. Oncotarget 2018, 9. [CrossRef]

87. Tang, H.; Song, C.; Ye, F.; Gao, G.; Ou, X.; Zhang, L.; Xie, X.; Xie, X. MiR-200c Suppresses Stemness and Increases Cellular Sensitivity to Trastuzumab in HER2+ Breast Cancer. J. Cell. Mol. Med. 2019, 23. [CrossRef]

88. Rogers, T.J.; Christenson, J.L.; Greene, L.I.; O’Neill, K.I.; Williams, M.M.; Gordon, M.A.; Nemkov, T.; D’Alessandro, A.; Degala, G.D.; Shin, J.; et al. Reversal of Triple-Negative Breast Cancer EMT by MiR-200c Decreases Tryptophan Catabolism and a Program of Immunosuppression. Mol. Cancer Res. 2019, 17. [CrossRef] [PubMed] 
89. Karimi Mazraehshah, M.; Tavangar, S.M.; Saidijam, M.; Amini, R.; Bahreini, F.; Karimi Dermani, F.; Najafi, R. Anticancer Effects of MiR-200c in Colorectal Cancer through BMI1. J. Cell. Biochem. 2018, 119. [CrossRef] [PubMed]

90. Xie, N.N.; Liu, Z.X.; Wu, C.; Wang, P.L.; Song, G.T.; Chen, Z. MicroRNA-200c Suppresses Tumor Metastasis in Oral Squamous Carcinoma by Inhibiting Epithelial-Mesenchymal Transition. Eur. Rev. Med Pharmacol. Sci. 2018, 22, 3415-3422. [CrossRef]

91. Oto, J.; Plana, E.; Fernández-Pardo, Á.; Cana, F.; Martínez-Sarmiento, M.; Vera-Donoso, C.D.; España, F.; Medina, P. Identification of MiR-29c-3p as a Robust Normalizer for Urine MicroRNA Studies in Bladder Cancer. Biomedicines 2020, 8, 447. [CrossRef]

92. Vilella, F.; Moreno-Moya, J.M.; Balaguer, N.; Grasso, A.; Herrero, M.; Martinez, S.; Marcilla, A.; Simon, C. Hsa-MiR-30d, Secreted by the Human Endometrium, Is Taken up by the Pre-Implantation Embryo and Might Modify Its Transcriptome. Development 2015, 142. [CrossRef] [PubMed]

93. Su, S.-F.; Chang, Y.-W.; Andreu-Vieyra, C.; Fang, J.Y.; Yang, Z.; Han, B.; Lee, A.S.; Liang, G. MiR-30d, MiR-181a and MiR-199a-5p Cooperatively Suppress the Endoplasmic Reticulum Chaperone and Signaling Regulator GRP78 in Cancer. Oncogene 2013, 32. [CrossRef]

94. Zhu, B.; Ekman, M.; Svensson, D.; Lindvall, J.M.; Nilsson, B.-O.; Uvelius, B.; Swärd, K. Array Profiling Reveals Contribution of Cthrc1 to Growth of the Denervated Rat Urinary Bladder. Am. J. Physiol. Ren. Physiol. 2018, 314. [CrossRef]

95. Liang, L.; Yang, Z.; Deng, Q.; Jiang, Y.; Cheng, Y.; Sun, Y.; Li, L. MiR-30d-5p Suppresses Proliferation and Autophagy by Targeting ATG5 in Renal Cell Carcinoma. FEBS Open Bio 2020. [CrossRef]

96. Hosseini, S.M.; Soltani, B.M.; Tavallaei, M.; Mowla, S.J.; Tafsiri, E.; Bagheri, A.; Khorshid, H. Clinically Significant Dysregulation of Hsa-MiR-30d-5p and Hsa-Let-7b Expression in Patients with Surgically Resected Non-Small Cell Lung Cancer. Avicenna J. Med. Biotechnol. 2018, 10, 98-104.

97. Yin, X.-H.; Jin, Y.-H.; Cao, Y.; Wong, Y.; Weng, H.; Sun, C.; Deng, J.-H.; Zeng, X.-T. Development of a 21-MiRNA Signature Associated with the Prognosis of Patients with Bladder Cancer. Front. Oncol. 2019, 9. [CrossRef]

98. Jiang, H.; Bu, Q.; Zeng, M.; Xia, D.; Wu, A. MicroRNA-93 Promotes Bladder Cancer Proliferation and Invasion by Targeting PEDF. Urol. Oncol. Semin. Orig. Investig. 2019, 37. [CrossRef]

99. Juracek, J.; Peltanova, B.; Dolezel, J.; Fedorko, M.; Pacik, D.; Radova, L.; Vesela, P.; Svoboda, M.; Slaby, O.; Stanik, M. GenomeWide Identification of Urinary Cell-Free MicroRNAs for Non-Invasive Detection of Bladder Cancer. J. Cell. Mol. Med. 2018, 22. [CrossRef]

100. Wang, J.; Liu, J.; Wang, H.; Wang, Y.; Li, Z.; Pan, Y.; Liu, Q.; Yang, M. Repression of the MiR-93-Enhanced Sensitivity of Bladder Carcinoma to Chemotherapy Involves the Regulation of LASS2. Oncotargets Ther. 2016. [CrossRef] [PubMed]

101. Armstrong, D.A.; Green, B.B.; Seigne, J.D.; Schned, A.R.; Marsit, C.J. MicroRNA Molecular Profiling from Matched Tumor and Bio-Fluids in Bladder Cancer. Mol. Cancer 2015, 14. [CrossRef]

102. Shi, X.; Liu, T.-T.; Yu, X.-N.; Balakrishnan, A.; Zhu, H.-R.; Guo, H.-Y.; Zhang, G.-C.; Bilegsaikhan, E.; Sun, J.-L.; Song, G.-Q.; et al. MicroRNA-93-5p Promotes Hepatocellular Carcinoma Progression via a MicroRNA-93-5p/MAP3K2/c-Jun Positive Feedback Circuit. Oncogene 2020, 39. [CrossRef]

103. Erdmann, K.; Salomo, K.; Klimova, A.; Heberling, U.; Lohse-Fischer, A.; Fuehrer, R.; Thomas, C.; Roeder, I.; Froehner, M.; Wirth, M.P.; et al. Urinary MicroRNAs as Potential Markers for Non-Invasive Diagnosis of Bladder Cancer. Int. J. Mol. Sci. 2020, $21,3814$. [CrossRef] [PubMed]

104. Liu, G.; Zhao, X.; Zhou, J.; Cheng, X.; Ye, Z.; Ji, Z. Long Non-Coding RNA MEG3 Suppresses the Development of Bladder Urothelial Carcinoma by Regulating MiR-96 and TPM1. Cancer Biol. Ther. 2018, 19. [CrossRef] [PubMed]

105. He, C.; Zhang, Q.; Gu, R.; Lou, Y.; Liu, W. MiR-96 Regulates Migration and Invasion of Bladder Cancer through EpithelialMesenchymal Transition in Response to Transforming Growth Factor-B1. J. Cell. Biochem. 2018, 119. [CrossRef] [PubMed]

106. Xu, T.; Du, X.; Hu, J.; Zhu, Y.; Wu, H.; Dai, G.; Shu, Y.; Ouyang, J. Anticancer Effect of MiR-96 Inhibitor in Bladder Cancer Cell Lines. Oncol. Lett. 2018. [CrossRef] [PubMed]

107. Wu, Z.; Liu, K.; Wang, Y.; Xu, Z.; Meng, J.; Gu, S. Upregulation of MicroRNA-96 and Its Oncogenic Functions by Targeting CDKN1A in Bladder Cancer. Cancer Cell Int. 2015, 15. [CrossRef] [PubMed]

108. Papadopoulos, E.I.; Scorilas, A. Cisplatin and Paclitaxel Alter the Expression Pattern of MiR-143/145 and MiR-183/96/182 Clusters in T24 Bladder Cancer Cells. Clin. Transl. Sci. 2015, 8. [CrossRef]

109. Luo, H.; Yang, L.; Liu, C.; Wang, X.; Dong, Q.; Liu, L.; Wei, Q. TMPO-AS1/MiR-98-5p/EBF1 Feedback Loop Contributes to the Progression of Bladder Cancer. Int. J. Biochem. Cell Biol. 2020, 122. [CrossRef] [PubMed]

110. Fırat, E.; Aybek, Z.; Akgün, S..; Küçüker, K.; Akça, H.; Aybek, H. Exploring Biomarkers in the Overactive Bladder: Alterations in MiRNA Levels of a Panel of Genes in Patients with OAB. Neurourol. Urodyn. 2019, 38. [CrossRef]

111. Luan, T.; Fu, S.; Huang, L.; Zuo, Y.; Ding, M.; Li, N.; Chen, J.; Wang, H.; Wang, J. MicroRNA-98 Promotes Drug Resistance and Regulates Mitochondrial Dynamics by Targeting LASS2 in Bladder Cancer Cells. Exp. Cell Res. 2018, 373. [CrossRef]

112. Feng, F.; Chen, A.; Huang, J.; Xia, Q.; Chen, Y.; Jin, X. Long Noncoding RNA SNHG16 Contributes to the Development of Bladder Cancer via Regulating MiR-98/STAT3/Wnt/B-catenin Pathway Axis. J. Cell. Biochem. 2018, 119. [CrossRef]

113. Sun, D.; Luo, X.; Ma, L.; Wang, Y.; Zhang, F. Identifying of MiR-98-5p/IGF1 Axis Contributes Breast Cancer Progression Using Comprehensive Bioinformatic Analyses Methods and Experiments Validation. Life Sci. 2020, 261. [CrossRef] [PubMed]

114. Yang, X.; Wang, P. MiR-188-5p and MiR-141-3p Influence Prognosis of Bladder Cancer and Promote Bladder Cancer Synergistically. Pathol. Res. Pract. 2019, 215. [CrossRef] [PubMed] 
115. Nekoohesh, L.; Modarressi, M.H.; Mowla, S.J.; Sadroddiny, E.; Etemadian, M.; Afsharpad, M.; Zolfaghari, F.; Barzegari, M.; Saffari, M.; Oskooei, V.K.; et al. Expression Profile of MiRNAs in Urine Samples of Bladder Cancer Patients. Biomark. Med. 2018, 12. [CrossRef] [PubMed]

116. Phatak, P.; Noe, M.; Asrani, K.; Chesnick, I.E.; Greenwald, B.D.; Donahue, J.M. MicroRNA-141-3p Regulates Cellular Proliferation, Migration, and Invasion in Esophageal Cancer by Targeting Tuberous Sclerosis Complex 1. Mol. Carcinog. 2020. [CrossRef]

117. Guan, G.; Niu, X.; Qiao, X.; Wang, X.; Liu, J.; Zhong, M. Upregulation of Neural Cell Adhesion Molecule 1 (NCAM1) by Hsa-MiR-141-3p Suppresses Ameloblastoma Cell Migration. Med. Sci. Monit. 2020, 26. [CrossRef]

118. Hernández-Rodríguez, R.T.; Amezcua-Guerra, L.M. The Potential Role of MicroRNAs as Biomarkers in Atopic Dermatitis: A Systematic Review. Eur. Rev. Med. Pharmacol. Sci. 2020, 24, 11804-11809. [CrossRef]

119. Zhang, Y.; Gao, T.; Li, X.; Wen, C.-C.; Yan, X.-T.; Peng, C.; Xiao, Y. Circ_0005075 Targeting MiR-151a-3p Promotes Neuropathic Pain in CCI Rats via Inducing NOTCH2 Expression. Gene 2021, 767. [CrossRef]

120. Liu, H.; Cheng, Y.; Xu, Y.; Xu, H.; Lin, Z.; Fan, J.; Lang, J. The Inhibition of Tumor Protein P53 by MicroRNA-151a-3p Induced Cell Proliferation, Migration and Invasion in Nasopharyngeal Carcinoma. Biosci. Rep. 2019, 39. [CrossRef] [PubMed]

121. Yue, C.; Chen, X.; Li, J.; Yang, X.; Li, Y.; Wen, Y. MiR-151-3p Inhibits Proliferation and Invasion of Colon Cancer Cell by Targeting Close Homolog of L1. J. Biomed. Nanotechnol. 2020, 16. [CrossRef]

122. Setti Boubaker, N.; Gurtner, A.; Trabelsi, N.; Manni, I.; Ayed, H.; Saadi, A.; Naimi, Z.; Ksontini, M.; Ayadi, M.; Blel, A.; et al. Uncovering the Expression Patterns and the Clinical Significance of MiR-182, MiR-205, MiR-27a and MiR-369 in Patients with Urinary Bladder Cancer. Mol. Biol. Rep. 2020, 47. [CrossRef]

123. Gu, C.; Zhao, K.; Zhou, N.; Liu, F.; Xie, F.; Yu, S.; Feng, Y.; Chen, L.; Yang, J.; Tian, F.; et al. UBAC2 Promotes Bladder Cancer Proliferation through BCRC-3/MiRNA-182-5p/P27 Axis. Cell Death Dis. 2020, 11. [CrossRef]

124. Wang, F.; Wu, D.; Xu, Z.; Chen, J.; Zhang, J.; Li, X.; Chen, S.; He, F.; Xu, J.; Su, L.; et al. MiR-182-5p Affects Human Bladder Cancer Cell Proliferation, Migration and Invasion through Regulating Cofilin 1. Cancer Cell Int. 2019, 19. [CrossRef] [PubMed]

125. Wu, M.; Zhang, Y. MiR-182 Inhibits Proliferation, Migration, Invasion and Inflammation of Endometrial Stromal Cells through Deactivation of NF-KB Signaling Pathway in Endometriosis. Mol. Cell. Biochem. 2021. [CrossRef]

126. Lu, B.; Yu, Y.; Xing, X.-L.; Liu, R.-Y. MiR-183/TMSB4Y, a New Potential Signaling Axis, Involving in the Progression of Laryngeal Cancer via Modulating Cell Adhesion. J. Recept. Signal Transduct. 2020. [CrossRef]

127. Chen, D.; Li, S.G.; Chen, J.Y.; Xiao, M. MiR-183 Maintains Canonical Wnt Signaling Activity and Regulates Growth and Apoptosis in Bladder Cancer via Targeting AXIN2. Eur. Rev. Med. Pharmacol. Sci. 2018, 22, 4828-4836. [CrossRef]

128. Yoshino, H.; Seki, N.; Itesako, T.; Chiyomaru, T.; Nakagawa, M.; Enokida, H. Aberrant Expression of MicroRNAs in Bladder Cancer. Nat. Rev. Urol. 2013, 10. [CrossRef]

129. Lan, X.; Wu, N.; Wu, L.; Qu, K.; Osoro, E.K.; Guan, D.; Du, X.; Wang, B.; Chen, S.; Miao, J.; et al. The Human Novel Gene LNC-HC Inhibits Hepatocellular Carcinoma Cell Proliferation by Sequestering Hsa-MiR-183-5p. Mol. Ther. Nucleic Acids 2020, 20. [CrossRef]

130. Li, Z.; Lin, C.; Zhao, L.; Zhou, L.; Pan, X.; Quan, J.; Peng, X.; Li, W.; Li, H.; Xu, J.; et al. Oncogene MiR-187-5p Is Associated with Cellular Proliferation, Migration, Invasion, Apoptosis and an Increased Risk of Recurrence in Bladder Cancer. Biomed. Pharmacother. 2018, 105. [CrossRef]

131. Huang, G.; Liang, M.; Liu, H.; Huang, J.; Li, P.; Wang, C.; Zhang, Y.; Lin, Y.; Jiang, X. CircRNA Hsa_circRNA_104348 Promotes Hepatocellular Carcinoma Progression through Modulating MiR-187-3p/RTKN2 Axis and Activating Wnt/ $\beta$-Catenin Pathway. Cell Death Dis. 2020, 11. [CrossRef]

132. Zheng, Y.; Yang, Z.; Jin, C.; Chen, C.; Wu, N. Hsa-MiR-191-5p Inhibits Replication of Human Immunodeficiency Virus Type 1 by Downregulating the Expression of NUP50. Arch. Virol. 2021. [CrossRef] [PubMed]

133. Ashirbekov, Y.; Abaildayev, A.; Omarbayeva, N.; Botbayev, D.; Belkozhayev, A.; Askandirova, A.; Neupokoyeva, A.; Utegenova, G.; Sharipov, K.; Aitkhozhina, N. Combination of Circulating MiR-145-5p/MiR-191-5p as Biomarker for Breast Cancer Detection. PeerJ 2020, 8. [CrossRef]

134. Emami, N.; Mohamadnia, A.; Mirzaei, M.; Bayat, M.; Mohammadi, F.; Bahrami, N. MiR-155, MiR-191, and MiR-494 as Diagnostic Biomarkers for Oral Squamous Cell Carcinoma and the Effects of Avastin on These Biomarkers. J. Korean Assoc. Oral Maxillofac. Surg. 2020, 46. [CrossRef]

135. Yang, C.; Ota-Kurogi, N.; Ikeda, K.; Okumura, T.; Horie-Inoue, K.; Takeda, S.; Inoue, S. MicroRNA-191 Regulates Endometrial Cancer Cell Growth via TET1-Mediated Epigenetic Modulation of APC. J. Biochem. 2020, 168. [CrossRef] [PubMed]

136. Pouliot, L.M.; Chen, Y.-C.; Bai, J.; Guha, R.; Martin, S.E.; Gottesman, M.M.; Hall, M.D. Cisplatin Sensitivity Mediated by WEE1 and CHK1 Is Mediated by MiR-155 and the MiR-15 Family. Cancer Res. 2012, 72, 5945-5955. [CrossRef]

137. Zhao, C.; Wang, G.; Zhu, Y.; Li, X.; Yan, F.; Zhang, C.; Huang, X.; Zhang, Y. Aberrant Regulation of MiR-15b in Human Malignant Tumors and Its Effects on the Hallmarks of Cancer. Tumor Biol. 2015, 37, 177-183. [CrossRef] [PubMed]

138. Finnerty, J.R.; Wang, W.-X.; Hébert, S.S.; Wilfred, B.R.; Mao, G.; Nelson, P.T. The MiR-15/107 Group of MicroRNA Genes: Evolutionary Biology, Cellular Functions, and Roles in Human Diseases. J. Mol. Biol. 2010, 402, 491-509. [CrossRef] [PubMed]

139. Xu, K.; Shi, J.; Mo, D.; Yang, Y.; Fu, Q.; Luo, Y. MiR-219a-1 Inhibits Colon Cancer Cells Proliferation and Invasion by Targeting MEMO1. Cancer Biol. Ther. 2020, 21. [CrossRef]

140. Wei, T.; Cheng, S.; Fu, X.N.; Feng, L.J. MiR-219a-5p Enhances the Radiosensitivity of Non-Small Cell Lung Cancer Cells through Targeting CD164. Biosci. Rep. 2020, 40. [CrossRef] [PubMed] 
141. Fan, H.; Jin, X.; Liao, C.; Qiao, L.; Zhao, W. MicroRNA-301b-3p Accelerates the Growth of Gastric Cancer Cells by Targeting Zinc Finger and BTB Domain Containing 4. Pathol. Res. Pract. 2019, 215. [CrossRef] [PubMed]

142. Yan, L.; Wang, Y.; Liang, J.; Liu, Z.; Sun, X.; Cai, K. MiR-301b Promotes the Proliferation, Mobility, and Epithelial-to-Mesenchymal Transition of Bladder Cancer Cells by Targeting EGR1. Biochem. Cell Biol. 2017, 95. [CrossRef] [PubMed]

143. Dong, X.; Chang, M.; Song, X.; Ding, S.; Xie, L.; Song, X. Plasma miR -1247-5p, miR -301b-3p and miR -105-5p as Potential Biomarkers for Early Diagnosis of Non-small Cell Lung Cancer. Thorac. Cancer 2020. [CrossRef]

144. Dos Santos Arcas, C.; Lin-Wang, H.T.; Umeda, I.I.K.; de Sousa, M.G.; Utiyama, D.M.O.; de Padua Mansur, A.; Macchione, M.; Hirata, M.H.; Nakagawa, N.K. Smoking Load Reduction Is Insufficient to Downregulate MiR-301b, a Lung Cancer Promoter. Sci. Rep. 2020, 10. [CrossRef]

145. Du, L.; Jiang, X.; Duan, W.; Wang, R.; Wang, L.; Zheng, G.; Yan, K.; Wang, L.; Li, J.; Zhang, X.; et al. Cell-Free MicroRNA Expression Signatures in Urine Serve as Novel Noninvasive Biomarkers for Diagnosis and Recurrence Prediction of Bladder Cancer. Oncotarget 2017, 8. [CrossRef] [PubMed]

146. Tao, J.; Yang, X.; Li, P.; Wei, J.; Deng, X.; Cheng, Y.; Qin, C.; Ju, X.; Meng, X.; Li, J.; et al. Identification of Circulating MicroRNA Signatures for Upper Tract Urothelial Carcinoma Detection. Mol. Med. Rep. 2015, 12. [CrossRef] [PubMed]

147. Liu, D.; Li, B.; Shi, X.; Zhang, J.; Chen, A.M.; Xu, J.; Wang, W.; Huang, K.; Gao, J.; Zheng, Z.; et al. Cross-Platform Genomic Identification and Clinical Validation of Breast Cancer Diagnostic Biomarkers. Aging 2021. [CrossRef]

148. Guo, C.M.; Liu, S.Q.; Sun, M.Z. MiR-429 as Biomarker for Diagnosis, Treatment and Prognosis of Cancers and Its Potential Action Mechanisms: A Systematic Literature Review. Neoplasma 2020, 67. [CrossRef] [PubMed]

149. Wu, C.-L.; Ho, J.-Y.; Hung, S.-H.; Yu, D.-S. MiR-429 Expression in Bladder Cancer and Its Correlation with Tumor Behavior and Clinical Outcome. Kaohsiung J. Med. Sci. 2018, 34. [CrossRef] [PubMed]

150. Yang, J.; Liu, Y.; He, A.; Liu, Y.; Wu, J.; Liao, X.; Lv, Z.; Wang, F.; Mei, H. Hsa-MiR-429 Promotes Bladder Cancer Cell Proliferation via Inhibiting CDKN2B. Oncotarget 2017, 8. [CrossRef] [PubMed]

151. Wu, C.-L.; Ho, J.-Y.; Chou, S.-C.; Yu, D.-S. MiR-429 Reverses Epithelial-Mesenchymal Transition by Restoring E-Cadherin Expression in Bladder Cancer. Oncotarget 2016, 7. [CrossRef] [PubMed]

152. Liu, X.; Zhao, W.; Wang, X. Inhibition of Long Non-Coding RNA MALAT1 Elevates MicroRNA-429 to Suppress the Progression of Hypopharyngeal Squamous Cell Carcinoma by Reducing ZEB1. Life Sci. 2020, 262. [CrossRef] [PubMed]

153. Zhang, W.; Liao, K.; Liu, D. MicroRNA-744-5p Is Downregulated in Colorectal Cancer and Targets SEPT2 to Suppress the Malignant Phenotype. Mol. Med. Rep. 2020, 23. [CrossRef]

154. Friedrich, M.; Vaxevanis, C.K.; Biehl, K.; Mueller, A.; Seliger, B. Targeting the Coding Sequence: Opposing Roles in Regulating Classical and Non-Classical MHC Class I Molecules by MiR-16 and MiR-744. J. Immunother. Cancer 2020, 8. [CrossRef]

155. Zhao, L.; Wang, J.; Li, J.; Li, Q. miR-744-5p Inhibits Cellular Proliferation and Invasion via Targeting ARF1 in Epithelial Ovarian Cancer. Kaohsiung J. Med. Sci. 2020, 36. [CrossRef] [PubMed]

156. Pilson, Q.; Smith, S.; Jefferies, C.A.; Ní Gabhann-Dromgoole, J.; Murphy, C.C. MiR-744-5p Contributes to Ocular Inflammation in Patients with Primary Sjogrens Syndrome. Sci. Rep. 2020, 10. [CrossRef]

157. Wang, R.; Wu, Y.; Huang, W.; Chen, W. MicroRNA-940 Targets INPP4A or GSK3 $\beta$ and Activates the Wnt/ $\beta$-Catenin Pathway to Regulate the Malignant Behavior of Bladder Cancer Cells. Oncol. Res. Featur. Preclin. Clin. Cancer Ther. 2018, 26. [CrossRef]

158. Ahadi, A. A Systematic Review of MicroRNAs as Potential Biomarkers for Diagnosis and Prognosis of Gastric Cancer. Immunogenetics 2021. [CrossRef]

159. Wu, Y.-P.; Lin, X.-D.; Chen, S.-H.; Ke, Z.-B.; Lin, F.; Chen, D.-N.; Xue, X.-Y.; Wei, Y.; Zheng, Q.-S.; Wen, Y.-A.; et al. Identification of Prostate Cancer-Related Circular RNA Through Bioinformatics Analysis. Front. Genet. 2020, 11. [CrossRef] [PubMed]

160. Jiang, P.; Han, W.; Fu, Y.; Chen, Q. The Hsa_circ_0091579/MiR-940/TACR1 Axis Regulates the Development of Hepatocellular Carcinoma. Cancer Manag. Res. 2020, 12. [CrossRef] [PubMed]

161. Zhang, B.; Li, F.; Zhu, Z.; Ding, A.; Luo, J. CircRNA CDR1as/MiR-1287/Raf1 Axis Modulates Hepatocellular Carcinoma Progression Through MEK/ERK Pathway. Cancer Manag. Res. 2020, 12. [CrossRef] [PubMed]

162. Chang, H.; Qu, J.; Wang, J.; Liang, X.; Sun, W. Circular RNA Circ_0026134 Regulates Non-Small Cell Lung Cancer Cell Proliferation and Invasion via Sponging MiR-1256 and MiR-1287. Biomed. Pharmacother. 2019, 112. [CrossRef] [PubMed]

163. Zheng, J.; Tan, Q.; Chen, H.; Chen, K.; Wang, H.; Chen, Z.; Xi, Y.; Yin, H.; Lai, K.; Liu, Y. LncRNA-SNHG7-003 Inhibits the Proliferation, Migration and Invasion of Vascular Smooth Muscle Cells by Targeting the MiR-1306-5p/SIRT7 Signaling Pathway. Int. J. Mol. Med. 2020, 47. [CrossRef]

164. Zhu, Z.; Rong, Z.; Luo, Z.; Yu, Z.; Zhang, J.; Qiu, Z.; Huang, C. Circular RNA CircNHSL1 Promotes Gastric Cancer Progression through the MiR-1306-3p/SIX1/Vimentin Axis. Mol. Cancer 2019, 18. [CrossRef]

165. Zhu, Z.; Rong, Z.; Luo, Z.; Yu, Z.; Zhang, J.; Qiu, Z.; Huang, C. Correction to: Circular RNA CircNHSL1 Promotes Gastric Cancer Progression through the MiR-1306-3p/SIX1/Vimentin Axis. Mol. Cancer 2020, 19. [CrossRef]

166. Ma, Y.; Zhou, A.; Song, J. Upregulation of MiR-1307-3p and Its Function in the Clinical Prognosis and Progression of Gastric Cancer. Oncol. Lett. 2020, 21. [CrossRef]

167. Eun, J.W.; Seo, C.W.; Baek, G.O.; Yoon, M.G.; Ahn, H.R.; Son, J.A.; Sung, S.; Kim, D.W.; Kim, S.S.; Cho, H.J.; et al. Circulating Exosomal MicroRNA-1307-5p as a Predictor for Metastasis in Patients with Hepatocellular Carcinoma. Cancers 2020, 12, 3819. [CrossRef] 
168. Du, X.; Wang, S.; Liu, X.; He, T.; Lin, X.; Wu, S.; Wang, D.; Li, J.; Huang, W.; Yang, H. MiR-1307-5p Targeting TRAF3 Upregulates the MAPK/NF-KB Pathway and Promotes Lung Adenocarcinoma Proliferation. Cancer Cell Int. 2020, 20. [CrossRef] [PubMed]

169. Stark, M.S.; Tyagi, S.; Nancarrow, D.J.; Boyle, G.M.; Cook, A.L.; Whiteman, D.C.; Parsons, P.G.; Schmidt, C.; Sturm, R.A.; Hayward, N.K. Characterization of the Melanoma MiRNAome by Deep Sequencing. PLoS ONE 2010, 5. [CrossRef]

170. Wang, S.; Cheng, Y.; Yang, P.; Qin, G. Silencing of Long Noncoding RNA LINC00324 Interacts with MicroRNA-3200-5p to Attenuate the Tumorigenesis of Gastric Cancer via Regulating BCAT1. Gastroenterol. Res. Pract. 2020. [CrossRef] [PubMed]

171. Hu, K.; Qin, X.; Shao, Y.; Zhou, Y.; Ye, G.; Xu, S. Circular RNA MTO1 Suppresses Tumorigenesis of Gastric Carcinoma by Sponging MiR-3200-5p and Targeting PEBP1. Mol. Cell. Probes 2020, 52. [CrossRef] [PubMed]

172. Wang, J.; Chu, X.Q.; Zhang, D.; Kong, D.F. Knockdown of Long Non-Coding RNA PEG10 Inhibits Growth, Migration and Invasion of Gastric Carcinoma Cells by up-Regulating MiR-3200. Neoplasma 2018, 65. [CrossRef]

173. Gu, Y.; Wang, W.; Wang, X.; Xie, H.; Ye, X.; Shu, P. Integrated Network Analysis Identifies Hsa-MiR-4756-3p as a Regulator of FOXM1 in Triple Negative Breast Cancer. Sci. Rep. 2019, 9. [CrossRef]

174. Jia, Y.; Zheng, Z.; Yang, Y.; Zou, M.; Li, J.; Wang, L.; Guan, M.; Xue, Y. MiR-4756 Promotes Albumin-induced Renal Tubular Epithelial Cell Epithelial-to-mesenchymal Transition and Endoplasmic Reticulum Stress via Targeting Sestrin2. J. Cell. Physiol. 2019, 234. [CrossRef]

175. Zhang, Y.; Li, P.; Hu, J.; Zhao, L.N.; Li, J.P.; Ma, R.; Li, W.W.; Shi, M.; Wei, L.C. Role and Mechanism of MiR-4778-3p and Its Targets NR2C2 and Med19 in Cervical Cancer Radioresistance. Biochem. Biophys. Res. Commun. 2019, 508. [CrossRef] [PubMed]

176. Wang, F.; Dai, M.; Chen, H.; Li, Y.; Zhang, J.; Zou, Z.; Yang, H. Prognostic Value of Hsa-mir-299 and Hsa-mir-7706 in Hepatocellular Carcinoma. Oncol. Lett. 2018. [CrossRef]

177. Zhang, Y.; Velez-Delgado, A.; Mathew, E.; Li, D.; Mendez, F.M.; Flannagan, K.; Rhim, A.D.; Simeone, D.M.; Beatty, G.L.; di Magliano, M.P. Myeloid Cells Are Required for PD-1/PD-L1 Checkpoint Activation and the Establishment of an Immunosuppressive Environment in Pancreatic Cancer. Gut 2016, 66, 124-136. [CrossRef]

178. Xu, S.; Tao, Z.; Hai, B.; Liang, H.; Shi, Y.; Wang, T.; Song, W.; Chen, Y.; OuYang, J.; Chen, J.; et al. MiR-424(322) Reverses Chemoresistance via T-Cell Immune Response Activation by Blocking the PD-L1 Immune Checkpoint. Nat. Commun. 2016, 7. [CrossRef] [PubMed]

179. Benjamini, Y.; Hochberg, Y. Controlling the False Discovery Rate: A Practical and Powerful Approach to Multiple Testing. J. R. Stat. Soc. Ser. B 1995, 57, 289-300. [CrossRef]

180. Weinstein, J.N.; Akbani, R.; Broom, B.M.; Wang, W.; Verhaak, R.G.W.; McConkey, D.; Lerner, S.; Morgan, M.; Creighton, C.J.; Smith, C.; et al. Comprehensive Molecular Characterization of Urothelial Bladder Carcinoma. Nature 2014, 507, 315-322. [CrossRef]

181. Colaprico, A.; Silva, T.C.; Olsen, C.; Garofano, L.; Cava, C.; Garolini, D.; Sabedot, T.S.; Malta, T.M.; Pagnotta, S.M.; Castiglioni, I.; et al. TCGAbiolinks: An R/Bioconductor Package for Integrative Analysis of TCGA Data. Nucleic Acids Res. 2015,44, e71. [CrossRef]

182. TCGA Correlations-Heatmaps. Available online: https:// corr.netlify.app (accessed on 8 January 2021). 